\title{
32. MAJOR AND MINOR ELEMENTS AND SULFUR ISOTOPES OF THE MESOZOIC AND CENOZOIC SEDIMENTS AT SITES 415 AND 416, LEG 50, DEEP SEA DRILLING PROJECT
}

\author{
A. A. Migdisov, Yu. P. Girin, E. M. Galimov, V. A. Grinenko, N. V. Barskaya, V. A. Krivitsky, \\ O. P. Sobornov, and S. L. Cherkovsky, V. I. Vernadsky Institute of Geochemistry and Analytical Chemistry, \\ U.S.S.R. Academy of Sciences, Moscow
}

\section{INTRODUCTION}

One of the major tasks of deep-sea drilling is accumulation of systematic data on the chemical composition of the sediments and sedimentary rocks found in various tectonic zones of the ocean. The global aspects of Earth's sedimentary cover can be discerned and better knowledge of the processes governing its evolution can be gained only by giving serious attention to the sedimentary layer of the ocean floor (Ronov and Yaroshevskii, 1976). Therefore, it is very important that representative material be selected for this purpose during the DSDP legs and that the Initial Reports regularly include analyses of an extensive complex of elements in sedimentary sections.

Samples derived from Sites 415 and 416 of Leg 50 in the Moroccan Basin, near the continental slope, indicate pelagic carbonate sediments and near-continent terrigenous and terrigenous-carbonate turbidites, according to the classification of Bogolepov and Chikov (1976). They can be assigned to the uppermost Jurassic, Cretaceous, and the Cenozoic. Galimov (this volume) treats the geochemistry of organic matter of these samples. The material was not ideal, because it represents only sporadic parts of the Cenozoic deposits, and even the best-sampled sequences of the Lower Cretaceous do not represent all the turbidite cycles. Nevertheless, the analyses of more than 40 samples give a general idea of the changes in chemical composition of the sedimentary rocks in the Moroccan Basin from the Tithonian to the Pleistocene.

The distributions of major and minor elements and sulfur isotope concentrations were studied. Major-element concentrations were determined from small weighed samples, using rapid chemical analysis, and photometric analyses as a final stage. Alkaline elements were analyzed by the flame-photometric method. The analysis of fluorine was made by a photocolorimetric method (Shemyakina, 1966). Copper, zinc, nickel, and cobalt concentrations were determined by atomic-absorption spectrophotometry. The samples were dissolved in a mixture of concentrated nitric, hydrofluoric and hydrochloric acids and subsequently placed in a 2 per cent $\mathrm{HCl}$ solution. Molybdenum and tin concentrations were determined by emission spectrography, using a diffraction spectrograph. Uranium, thorium, and potassium concentrations were determined by $\gamma$-spectrometry, using the method described by Sobornov and Polyakov (1975). In addition to the bulk silicate analyses, the content of water-soluble sodium and the content of amorphous silica ( 5 per cent sodium extract) were found.

The analyses of the rock and sediment samples from the Leg 50 sites were accompanied by analyses of reference samples of the ZGI rocks and also standards adopted by the U.S. National Bureau of Standards for major elements, which allowed us to prove the reliability of the individual values of the results obtained (Tables 1 and 2).

All the analyses were conducted on air-dried, weighed samples. Sea salts were not washed off the rock samples. This should be taken into account when evaluating the totals of the silicate analyses and interpreting the data on sodium. The addition of potassium, magnesium, and other elements to the samples from interstitial waters was not significant. To conduct isotopic analysis, sulfur of water-soluble sulfate and the total of pyritic and free sulfur were isolated from rocks and sediments, according to the method described by Volkov and Zhabina (1977). Because free sulfur is normally scarce in rocks, the sulfur of the second category will be pyrite sulfur. Isotopic measurements were conducted with an M-1305 mass spectrometer with a precision of 0.3 per mill (Ustinov and Grinenko, 1965).

\section{DISTRIBUTION OF MAJOR ELEMENTS} 4.

Major-element analyses are presented in Tables 3 and

Among the sediments and rocks drilled at Sites 415 and 416 , carbonate rocks are abundant. It is natural, therefore, to consider first the distribution of carbon dioxide, calcium, and magnesium, interval by interval. As can be seen from Figure 1, the $\mathrm{CO}_{2}$ content ranges from 0 to 40 per cent, commonly exhibiting great variations within a short vertical distance, as a consequence of fine interbedding, particularly in turbidites. The calcium content fluctuates with the variations in carbon dioxide, whereas magnesium varies contrarily. An inverse correlation between $\mathrm{CO}_{2}$ and the ratio $\mathrm{MgO} / \mathrm{CaO}$ (Figure 2) indicates that a great proportion of magnesium is found in terrigenous silicates. The rocks, certainly, contain diagenetic dolomite, ankerite and siderite rhombohedrons, but according to the chemical analyses, their amount is insignificant; they constitute a considerable proportion of the carbonates only where the 
TABLE 1

Chemical Analyses of Standard Samples

\begin{tabular}{|c|c|c|c|c|c|c|c|c|c|c|c|c|}
\hline & \multirow{2}{*}{\multicolumn{2}{|c|}{ TB-ZGI, Slate }} & \multicolumn{2}{|c|}{ TS-ZGI, Slate } & \multicolumn{2}{|c|}{ KH-ZGI, Limestone } & \multicolumn{6}{|c|}{ Standard Samples, U. S. Nat. Bureau of Standards } \\
\hline & & & & & & Flanagan & No 76 , Burnt & Refr. & No 102 , Silic & $\mathrm{Br}$. & No 78 , Burnt & Refr. \\
\hline & Results & $(1973)^{\mathrm{a}}$ & Results & $(1973)^{\mathrm{a}}$ & Results & $(1973)^{\mathrm{a}}$ & Results & Certif. & Results & Certif. & Results & Certif. \\
\hline $\mathrm{SiO}_{2}$ & 59.80 & 60.30 & 62.40 & 62.8 & 9.0 & 8.61 & 54.28 & 54.68 & 93.98 & 93.94 & 20.60 & 20.69 \\
\hline $\mathrm{TiO}_{2}$ & 0.80 & 0.93 & 0.66 & 0.73 & 0.12 & 0.13 & 2.20 & 2.21 & 0.14 & 0.16 & 3.32 & 3.37 \\
\hline $\mathrm{Al}_{2} \mathrm{O}_{3}$ & 21.10 & 20.55 & 16.40 & 16.05 & 2.80 & 2.41 & 37.00 & 37.67 & 1.99 & 1.96 & & \\
\hline Total Fe as & & & & & & & & & & & & \\
\hline $\mathrm{Fe}_{2} \mathrm{O}_{3}$ & 6.85 & 6.92 & 7.50 & 7.30 & 1.10 & 0.93 & 2.20 & 2.38 & 0.80 & 0.66 & 0.76 & 0.79 \\
\hline $\mathrm{MgO}$ & 1.97 & 1.94 & 1.90 & 1.79 & 0.45 & 0.72 & 0.68 & 0.58 & 0.30 & 0.21 & 0.60 & 0.51 \\
\hline $\mathrm{CaO}$ & tr. & 0.30 & 0.28 & 0.16 & 47.86 & 47.76 & 0.28 & 0.27 & 2.38 & 2.29 & 0.42 & 0.38 \\
\hline $\mathrm{P}_{2} \mathrm{O}_{5}$ & 0.125 & 0.10 & 0.28 & 0.28 & 0.08 & 0.12 & & & & & & \\
\hline $\mathrm{MnO}$ & 0.09 & 0,05 & 0.04 & 0.04 & 0.09 & 0.09 & 0.03 & 0.02 & 0.014 & 0.010 & & \\
\hline $\mathrm{K}_{2} \mathrm{O}$ & 3.95 & 3.85 & 4.97 & 4.87 & & & & & & & & \\
\hline $\mathrm{Na}_{2} \mathrm{O}$ & 1.24 & 1.31 & 0.10 & 0.10 & & & & & & & & \\
\hline Loss on ign. & 3.42 & 3.95 & 5.88 & 5.45 & 38.83 & 38.60 & & & & & & \\
\hline Analysts & E. V. Bezrogova & & E. V. Bezrogova & & N. V. Budarina & & N. V. Barskaja & & N. V. Barskaja & & N. V. Barskaja & \\
\hline
\end{tabular}

aF, L. 17lanagan, 1973. Values for international geochemical reference samples, Geochim. Cosmochim. Acta, v. 37, pp. 1189-1200.

TABLE 2

Minor-Element Analyses in Standard Samples (ppm)

\begin{tabular}{|c|c|c|c|c|c|c|c|c|c|c|}
\hline $\begin{array}{l}\text { Method of } \\
\text { Determination }\end{array}$ & Element & $\begin{array}{l}\text { GM-ZG } \\
\text { Results }\end{array}$ & $\begin{array}{l}\text { Granite } \\
\text { Flanagan } \\
(1973)^{\mathrm{a}}\end{array}$ & $\begin{array}{r}\text { BM-ZC } \\
\text { Results }\end{array}$ & $\begin{array}{l}\text { I, Basalt } \\
\text { Flanagan } \\
(1973)^{\mathrm{a}}\end{array}$ & $\begin{array}{r}\text { TB-ZC } \\
\text { Results }\end{array}$ & $\begin{array}{l}\text { 1, Slate } \\
\text { Flanagan } \\
(1973)^{a}\end{array}$ & $\begin{array}{l}\text { KH-ZGI, } \\
\text { Results }\end{array}$ & $\begin{array}{l}\text { Limestone } \\
\text { Flanagan } \\
(1973)^{\mathrm{a}}\end{array}$ & Analyst \\
\hline Colorimetry & $\mathrm{F}$ & 600 & 675 & 310 & 250 & 700 & 715 & 500 & 570 & A. 1. Ermishkina \\
\hline $\begin{array}{l}\text { Flame- } \\
\text { photometry }\end{array}$ & $\begin{array}{l}\mathrm{Li} \\
\mathrm{Rb}\end{array}$ & $\begin{array}{r}50 \\
256\end{array}$ & $\begin{array}{r}51 \\
250\end{array}$ & $\begin{array}{l}72 \\
13\end{array}$ & $\begin{array}{l}70 \\
12\end{array}$ & $\begin{array}{l}113 \\
179\end{array}$ & $\begin{array}{l}114 \\
178\end{array}$ & $\begin{array}{r}8 \\
32\end{array}$ & $\begin{array}{l}8.5 \\
30\end{array}$ & V. A. Krivitzki \\
\hline $\begin{array}{l}\text { Atomic } \\
\text { Absorption }\end{array}$ & $\begin{array}{l}\mathrm{Cu} \\
\mathrm{Zn} \\
\mathrm{Ni} \\
\mathrm{Co}\end{array}$ & $\begin{array}{r}18 \\
40 \\
7 \\
-\end{array}$ & $\begin{array}{l}13 \\
40 \\
7.5 \\
3.5\end{array}$ & $\begin{array}{r}43 \\
110 \\
48 \\
41\end{array}$ & $\begin{array}{r}45 \\
107 \\
57 \\
34\end{array}$ & $\begin{array}{l}49 \\
96 \\
37 \\
15\end{array}$ & $\begin{array}{l}50 \\
95 \\
40 \\
13\end{array}$ & $\begin{array}{r}13 \\
24 \\
16 \\
5\end{array}$ & $\begin{array}{r}10 \\
11 \\
20 \\
4\end{array}$ & E. M. Sedikh \\
\hline $\begin{array}{l}\text { Emission } \\
\text { Spectrometry }\end{array}$ & $\begin{array}{l}\text { Mo } \\
\text { Sn }\end{array}$ & $\begin{array}{l}1.0 \\
4.5\end{array}$ & $\begin{array}{l}1.1 \\
4.6\end{array}$ & $\begin{array}{l}0.4 \\
15\end{array}$ & $\begin{array}{l}0.6 \\
12\end{array}$ & $\begin{array}{l}0.6 \\
4.7\end{array}$ & $\begin{array}{l}1.0 \\
5.7\end{array}$ & $\begin{array}{l}0.4 \\
1.0\end{array}$ & - & V. P. Shvedkova \\
\hline$\gamma$-Spectrometry & $\begin{array}{l}\mathrm{U}_{(\mathrm{Ra})} \\
\mathrm{Th}\end{array}$ & $\begin{array}{r}6.6 \\
34.2\end{array}$ & 35 & $\begin{array}{l}0.7 \\
3.0\end{array}$ & $\begin{array}{l}1 \\
3\end{array}$ & $\begin{array}{r}2.4 \\
18.3\end{array}$ & $\begin{array}{r}3 \\
19\end{array}$ & $\begin{array}{l}0.8 \\
2.0\end{array}$ & $\begin{array}{l}1 \\
3\end{array}$ & O.P. Sobornov \\
\hline
\end{tabular}

${ }^{a}$ Flanagan, F. L., 1973. Values for international geochemical reference samples, Geochim. Cosmochim. Acta, v. 37, pp. $1189-1200$.

TABLE 3

Major-Element Analyses (\%), Site 415

\begin{tabular}{|c|c|c|c|c|c|c|c|c|c|c|c|c|c|c|c|c|c|c|}
\hline $\begin{array}{c}\text { Sample } \\
\text { (interval in } \mathrm{cm} \text { ) }\end{array}$ & $\begin{array}{l}\text { Sub-Bottom } \\
\text { Depth of Core } \\
\text { (m) }\end{array}$ & $\mathrm{SiO}_{2}$ & $\mathrm{TiO}_{2}$ & $\mathrm{Al}_{2} \mathrm{O}_{3}$ & $\mathrm{Fe}_{2} \mathrm{O}_{3}$ & $\mathrm{FeO}$ & $\mathrm{MgO}$ & $\mathrm{CaO}$ & $\mathrm{P}_{2} \mathrm{O}_{5}$ & $\mathrm{MnO}$ & $\mathrm{K}_{2} \mathrm{O}$ & $\mathrm{Na}_{2} \mathrm{O}$ & $\mathrm{CO}_{2}$ & $\mathrm{C}_{\text {org }}$ & $\begin{array}{l}\text { L.o.i. } \\
\left(\approx \mathrm{H}_{2} \mathrm{O}\right)\end{array}$ & $\begin{array}{c}\text { Total } \\
\text { (without } \mathrm{Cl} \\
\text { and } \mathrm{SO}_{3} \text { ) }\end{array}$ & $\begin{array}{l}\mathrm{Na}_{2} \mathrm{O} \\
\text { (water- } \\
\text { soluble) }\end{array}$ & $\begin{array}{c}\mathrm{SiO}_{2} \\
\text { (Opaline) }\end{array}$ \\
\hline $415-1-5.37-62$ & $0-7.5$ & 23.90 & 0.33 & 7.10 & 2.22 & 0.89 & 2.18 & 29.81 & 0.16 & $<0.02$ & 1.89 & 1.75 & 22.92 & 0.12 & 5.38 & 98.67 & 1.17 & 3.10 \\
\hline $2-1,46-72$ & $74-83.5$ & 18.60 & 0.22 & 5.20 & 1.57 & 0.71 & 1.65 & 35.42 & 0.14 & 0.04 & 1.35 & 1.38 & 28.60 & 0.13 & 4.01 & 99.02 & 0.39 & 3.04 \\
\hline $3-1,31-50$ & $137.5-147$ & 17.80 & 0.30 & 5.95 & 1.68 & 0.58 & 1.44 & 34.70 & 0.235 & 0.032 & 1.41 & 1.76 & 27.59 & 0.19 & 5.82 & 99.57 & 0.55 & 2.56 \\
\hline $4-5,114-135$ & $207-216.5$ & 13.60 & 0.12 & 2.40 & 1.03 & 0.38 & 1.01 & 43.28 & 0.06 & $<0.02$ & 0.68 & 0.67 & 33.04 & 0.10 & 3.30 & 99.69 & 0.37 & 2.20 \\
\hline $5-2,32-59$ & $273.5-283$ & 27.60 & 0.22 & 4.95 & 2.03 & 0.47 & 2.38 & 29,81 & 0.33 & $<0.02$ & 1.50 & 0.98 & 22.46 & 0.19 & 5,80 & 98.74 & 0.64 & 2.65 \\
\hline $5-3,71-73$ & $273.5-283$ & 22.30 & 0.18 & 3.40 & 1.59 & 0.46 & 1.00 & 35.93 & 0.18 & 0.02 & 1.01 & 1.08 & 27.05 & & 4.67 & 98.87 & 0.59 & 2.96 \\
\hline $415 \mathrm{~A}-5-1,76-78$ & $443-452.5$ & 64.20 & 0.47 & 11.10 & 3.54 & 0.46 & 2.35 & 1.68 & 0.47 & 0.05 & 1.11 & 2.13 & - & & 10.81 & 98.37 & 1.05 & 19.20 \\
\hline $5-1,101-126$ & $443-452.5$ & 65.40 & 0.45 & 11.20 & 3.59 & 0.83 & 2.48 & 0.70 & 0.29 & 0.07 & 1.17 & 2.08 & - & 0.19 & 10. & 98 & 0.56 & 11.60 \\
\hline $6-1,75-77$ & $452.5-509.5$ & 9.90 & 0.08 & 1.40 & 0.97 & 0.21 & 0.29 & 46.17 & 0.40 & 0.20 & 0.28 & 0.79 & 36.12 & & 2.56 & 99.37 & 0.40 & 5.12 \\
\hline $6-2,56-77$ & $452.5-509.5$ & 40.00 & 0.16 & 3.90 & 0.93 & 1.15 & 3.13 & 22.88 & 0.58 & $<0.02$ & 0.93 & 0.92 & 17.31 & 0.20 & 5.82 & 97.93 & 0.42 & 12.60 \\
\hline $8-1,50-80$ & $519-585.5$ & 50.02 & 0.86 & 14.20 & 1.16 & 4.17 & 3.79 & 4.27 & 0.14 & $<0.02$ & 1.28 & 1.74 & 4.51 & 1.14 & 10.61 & 97.91 & 1.07 & 4.00 \\
\hline $8-1,4-6$ & $519-585.5$ & & & & & & & & & & 1.71 & 1.94 & & & & & 1.03 & \\
\hline $9-1,28-50$ & $642.5-652$ & 33.80 & 0.66 & 10.90 & 3.07 & 1.53 & 2.02 & 20.21 & 0.11 & $<0.02$ & 0.66 & 1.19 & 16.48 & 0.66 & 6.96 & 98.27 & 0.71 & 3.12 \\
\hline $9-3,130-132$ & $642.5-652$ & 10.70 & 0.20 & 3.10 & 1.38 & 0.69 & 0.14 & 44.35 & $<0.03$ & 0.11 & 0.28 & 0.36 & 34.98 & & 1.95 & 98.27 & 0.29 & \\
\hline $10-2,110-136$ & $709-718.5$ & 35.90 & 0.57 & 11.30 & 4.63 & 0.69 & 3.37 & 17.12 & $<0.03$ & 0.11 & 1.65 & 0.86 & 15.61 & 0.29 & 6.27 & 98.40 & 0.50 & \\
\hline $10, \mathrm{CC}, 10-12$ & $709-718.5$ & & & & & & & & & & 0.97 & 0.81 & & & & & 0.40 & \\
\hline $12-1,15-17$ & $880-889.5$ & 39.40 & 0.70 & 11.80 & 4.03 & 0.83 & 1.08 & 17.54 & 0.10 & 0.05 & 1.30 & 0.80 & 13.62 & & 6.5 & 97.83 & 0.73 & 5.28 \\
\hline $12-2,70-95$ & $880-889.5$ & 46.00 & 0.71 & 12.75 & 4.59 & 1.27 & 2.62 & 10.67 & 0.03 & $<0.02$ & 1.43 & 1.30 & 9.90 & 0.68 & 7.03 & 99.00 & 0.36 & \\
\hline $13-2,85-87$ & $956-965.5$ & 45.70 & 0.66 & 12.40 & 3.73 & 1.19 & 2.04 & 12.07 & 0.08 & 0.02 & 1.38 & 1.09 & 10.32 & & 7.26 & 97.94 & 1.00 & 3.44 \\
\hline $13-1.81-131$ & $956-965.5$ & 27.60 & 0.42 & 10.00 & 2.53 & 3.92 & 6.94 & 18.53 & 0.16 & $<0.02$ & 0.82 & 0.74 & 21.87 & 0.34 & 6.14 & 99.80 & 0.81 & \\
\hline $14-1.15-17$ & $1032-1041.5$ & 25.80 & 0.48 & 9.50 & 2.84 & 1.18 & 3.29 & 25.68 & 0.08 & 0.08 & 0.86 & 0.78 & 22.66 & & 5.93 & 99.17 & 0.51 & \\
\hline $14-2.3-6$ & $1032-1041.5$ & 43.04 & 0.80 & 11.20 & 2.59 & 3.69 & 2.12 & 12.49 & 0.09 & $<0.02$ & 1.02 & 1.11 & 10.03 & 0.57 & 9.65 & 98.42 & 0.66 & 3.12 \\
\hline
\end{tabular}

carbonate content of the rock is as low as a few per cent. It is only the Albian samples that show an essential accumulation of magnesium carbonate, normative dolomite accounting for up to 30 per cent of the weight of the rock.
Because terrigenous sedimentary material was periodically diluted by biogenic (pelagic) calcium carbonate, it is expedient to use concentrations calculated on the basis of carbonate-free samples to describe chemical variations in the terrigenous sedimentary material. Oth- 
TABLE 4

Major-Element Analyses (\%), Site 416

\begin{tabular}{|c|c|c|c|c|c|c|c|c|c|c|c|c|c|c|c|c|c|c|c|}
\hline $\begin{array}{c}\text { Sample } \\
\text { (interval in cm) }\end{array}$ & $\begin{array}{l}\text { Sub-Bottom } \\
\text { Depth of Core } \\
\text { (m) }\end{array}$ & $\mathrm{SiO}_{2}$ & $\mathrm{TiO}_{2}$ & $\mathrm{Al}_{2} \mathrm{O}_{3}$ & $\mathrm{Fe}_{2} \mathrm{O}_{3}$ & $\mathrm{FeO}$ & $\mathrm{MgO}$ & $\mathrm{CaO}$ & $\mathrm{P}_{2} \mathrm{O}_{5}$ & $\mathrm{MnO}$ & $\mathrm{K}_{2} \mathrm{O}$ & $\mathrm{Na}_{2} \mathrm{O}$ & $\mathrm{CO}_{2}$ & Corg & $\begin{array}{c}\text { L.o.i. } \\
\left(\approx \mathrm{H}_{2} \mathrm{O}\right)\end{array}$ & $\begin{array}{c}\text { Total } \\
\text { (without } \mathrm{Cl} \\
\text { and } \mathrm{SO}_{3} \text { ) }\end{array}$ & $\begin{array}{l}\mathrm{Na}_{2} \mathrm{O} \\
\text { (water- } \\
\text { soluble) }\end{array}$ & $\begin{array}{c}\mathrm{SiO}_{2} \\
\text { (Opaline) }\end{array}$ & $\mathrm{H}_{2} \mathrm{O}^{-}$ \\
\hline $416 \mathrm{~A}-1-1,115-140$ & $146-155.5$ & 32.60 & 0.43 & 7.65 & 1.66 & 1.97 & 4.92 & 22.12 & 0.23 & $<0.02$ & 2.18 & 1.16 & 18.59 & 0.15 & 6.12 & 99.80 & 0.55 & 3.12 & \\
\hline $\begin{array}{r}2-2,56-74 \\
79-91\end{array}$ & $298-304.5$ & 45.10 & 0.57 & 10.70 & 3.10 & 1.13 & 4.40 & 12.07 & 0.28 & 0.08 & 2.89 & 1.19 & 11.51 & 0.50 & 5.48 & 99.00 & & 4.50 & \\
\hline $\begin{array}{l}3-1,72-76 \\
3-3,60-87\end{array}$ & $\begin{array}{l}450-459.5 \\
450-459.5\end{array}$ & 46.10 & 0.57 & 8.90 & 3.16 & 0.89 & 3.75 & 13.81 & 0.32 & 0.08 & $\begin{array}{l}2.11 \\
2.48\end{array}$ & $\begin{array}{l}1.27 \\
1.19\end{array}$ & 12.91 & 0.75 & 4.37 & 98.24 & 0.50 & $\begin{array}{l}3.60 \\
4.70\end{array}$ & \\
\hline $\begin{array}{l}6-3,29-75 \\
7-2,36-47\end{array}$ & $887-896.5$ & 61.50 & 0.84 & 15.86 & 5.06 & 0.72 & 2.63 & 0.62 & 0.216 & 0.035 & 3.51 & 1.41 & 0.18 & 0.58 & 7.04 & 100.02 & 0.26 & & 2.10 \\
\hline $\begin{array}{c}48-69 \\
9-3,114-117\end{array}$ & $991.5-1093$ & 52.00 & 0.92 & 19.02 & 3.56 & 3.06 & 2.74 & 3.94 & 0.170 & 0.050 & 3.39 & 1.19 & 3.38 & 0.29 & 6.59 & 100.35 & 0.36 & 2.48 & 1.68 \\
\hline $\begin{array}{l}119-134 \\
139-143\end{array}$ & $1176.9-1185.4$ & 47.32 & 0.76 & 12.50 & 3.50 & 1.35 & 2.32 & 12.62 & 0.126 & 0.060 & 2.58 & 1.44 & 10.78 & 0.37 & 4.61 & 100.21 & 0.30 & 2.86 & 1.72 \\
\hline $11-4,61-81$ & $1194.8-1204.3$ & 41.40 & 0.71 & 15.00 & 3.31 & 5.40 & 2.70 & 8.84 & 0.08 & 0.04 & 2.64 & 0.99 & 9.62 & 0.39 & 6.89 & 98.01 & 0.43 & & \\
\hline $\begin{array}{l}13-2,79-100 \\
15-1,64-100\end{array}$ & $1213.8-1222.4$ & 45.80 & 0.83 & 16.50 & 6.45 & & 2.30 & 8.14 & 0.08 & $<0.02$ & 3.07 & 1.05 & 7.67 & 0.38 & 5.87 & 98.16 & 0.49 & & \\
\hline $\begin{array}{r}104-111 \\
143-150\end{array}$ & $1232.9-1242.5$ & 43.52 & 0.86 & 15.57 & 3.77 & 3.68 & 2.75 & 9.86 & 0.146 & 0.090 & 2.81 & 1.17 & 8.94 & 0.30 & 6.56 & 100.03 & 0.44 & 4.16 & 1.64 \\
\hline $20-2,0-50$ & $1277.5-1287$ & 46.54 & 0.82 & 18.9 & 3.46 & 3.51 & 3.71 & 5. & 0.175 & 0.066 & 3.75 & 1. & 5.12 & 0.40 & 6.9 & 100.22 & 0.68 & 4.60 & 1.76 \\
\hline $22-3,68-86$ & $1299.5-1309.1$ & 39.40 & 0.84 & 15.40 & 2. & 3.10 & 2.70 & 13.55 & 0.136 & 0 & 2.94 & 1.17 & 11.26 & 0.37 & 6.9 & 100.96 & 0.51 & & 2.00 \\
\hline $27-1,68-118$ & $1327.7-1336.2$ & 53.02 & 0.90 & 19.5 & 5.74 & 2.79 & 2.98 & 1.55 & 0.175 & 0.130 & 3.68 & 1.4 & 1.12 & 0.53 & 7.0 & 100.53 & 0.54 & & 2.06 \\
\hline $25-1,6-60$ & $1327.7-1336.7$ & 54.53 & 0.94 & 18.07 & 4.04 & 1.92 & 3.15 & 2.70 & 0.120 & 0.052 & 3.63 & 1.70 & 2.11 & 0.43 & 6.28 & 99.67 & 0.49 & 4.98 & 1.80 \\
\hline $29-2,10-40$ & $1365.7-1375.2$ & 50.72 & 0.98 & 19.00 & 3.38 & 3.62 & 3.10 & 2.95 & 0.126 & 0.070 & 3.91 & 1.3 & 3.54 & 0.41 & 6.6 & 99.83 & 0.56 & & 2.20 \\
\hline $31-4,32-74$ & $1384.6-1394.1$ & 52.50 & 0.94 & 18.56 & 5.28 & 1.78 & 3.58 & 1.98 & 0.140 & 0.067 & 3.97 & 1.44 & 1.91 & 0.31 & 6.9 & 99.36 & 0.51 & 4.48 & 2.40 \\
\hline $40-3,95-125$ & $1454.5-1463.9$ & 42.46 & 0.70 & 13.81 & 4.46 & 1.75 & 3.39 & 13.41 & 0.155 & 0.062 & 2.98 & 1.16 & 10.06 & 0.05 & 5.5 & 100.00 & 0.32 & 4.20 & 1.74 \\
\hline $44-2,57-91$ & $1491.9-1501.2$ & 49.98 & 0.82 & 17.87 & 5.03 & 1.79 & 3.19 & 5.52 & 0.162 & 0.050 & 3.33 & 1.2 & 4.21 & 0.11 & 6.44 & 99.78 & 0.24 & 4,00 & 2.28 \\
\hline $47-2,108-150$ & $1520-1529.5$ & 43.34 & 0.72 & 16.64 & 5.05 & 1.67 & 2.35 & 11.07 & 0.142 & 0.060 & 3.22 & 1.00 & 8.74 & 0.06 & 6.06 & 100.12 & 0.34 & & 2.02 \\
\hline $50-2,31-81$ & $1548.6-1558$ & 49.86 & 0.96 & 17.84 & 4.23 & 3.16 & 2.96 & 5.55 & 0.136 & 0.042 & 3.39 & 1.19 & 4.14 & 0.66 & 6.28 & 100.40 & 0.47 & 4.32 & 2.90 \\
\hline $52-2,14-16$ & $1567.4-1576.8$ & 56.8 & 0.372 & 4.10 & 0.65 & 0.86 & 1.07 & 16.84 & $<0.03$ & 0.08 & 1.08 & 0.72 & 14.06 & & 1.49 & & 0.07 & 3.20 & \\
\hline $57-1,64-72$ & $1614.5-1624.0$ & 6.5 & 0.080 & 1.35 & 0.73 & 0.69 & 1.39 & 48.26 & $<0.03$ & 0.05 & 0.46 & 0.23 & 39.56 & & 0.49 & 99.82 & 0.16 & 2.30 & \\
\hline
\end{tabular}

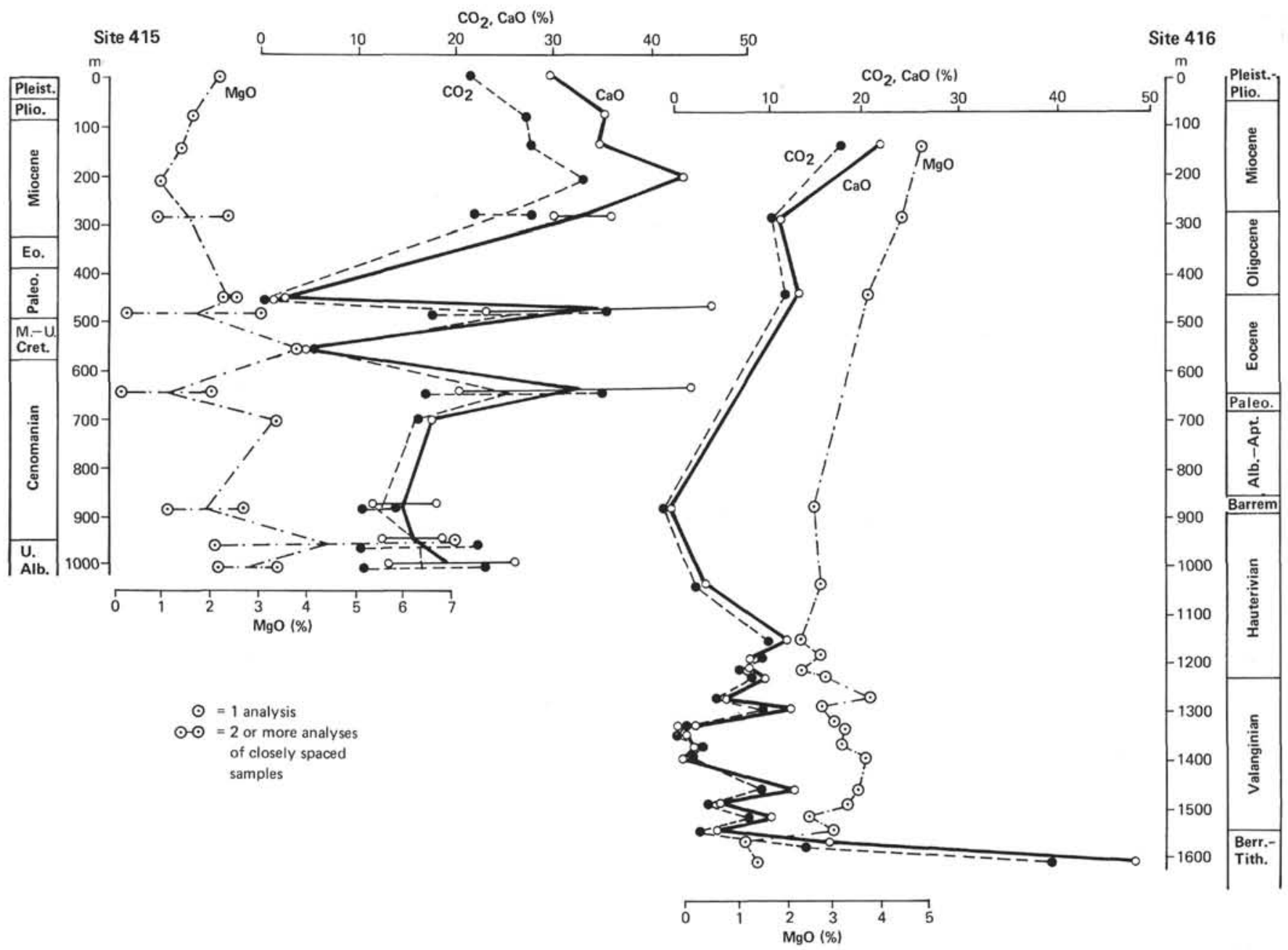

Figure 1. Distribution of $\mathrm{CaO}, \mathrm{MgO}$, and $\mathrm{CO}_{2}$, Sites 415 and 416 . 


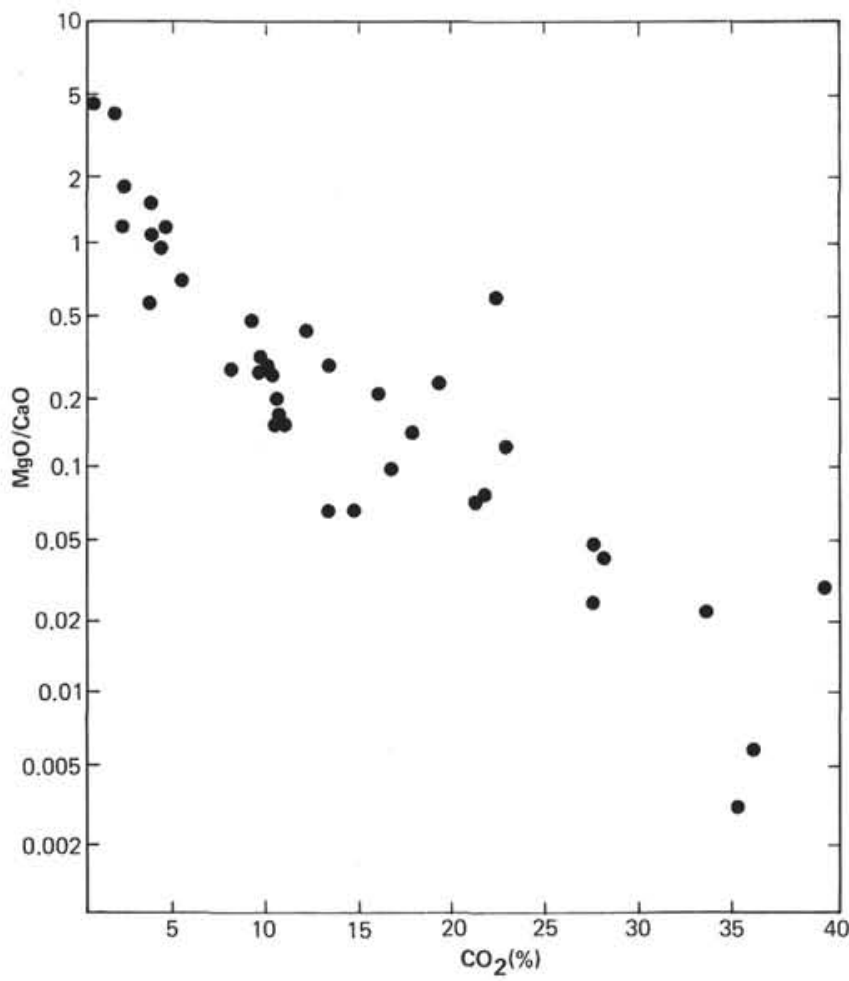

Figure 2. Variation of $\mathrm{MgO} / \mathrm{CaO}$ as a function of $\mathrm{CO}_{2}$ content, Sites 415 and 416.

erwise, the good correlations which can be observed among most elements are obscured, and there is no correlation of most of the elements with carbonate.

The concentrations of the major components of terrigenous material, silica and alumina, usually vary inversely through the section (Figure 3 ). The highest alumina concentrations are in the lower part of the section (Lower Cretaceous), particularly in the Valanginian and Hauterivian (Site 416). This points to influx of essentially mature pelitic material from the continent during the Cretaceous. An increase in silica is observed in the Paleogene, particularly in the Paleocene (Site 415). Lithologic data, however, indicate that it is not terrigenous, but is a biogenic admixture. The maximum amount of amorphous silica is found here too: about 21 per cent in the carbonate-free material (Site 415, Figure 4). Opaline silica normally accounts for 10 to 15 per cent of the total silica; in the turbidites of the Lower Cretaceous (Site 416) it decreases to 5 to 7 per cent. The alumina-silica ratio (Figure 3) fluctuates significantly through the section, the highest values $(0.4)$ being characteristic of the Hauterivian (Site 416) and the lowest $(0.1)$ of the Paleocene (Site 415). When opaline silica is taken into account, the ratio is somewhat higher for the Paleocene, but it is still at its minimum here. A still lower ratio, about 0.05 , was recorded in the Tithonian (Site 416); it corresponds to silt-sand rocks whose low ratio reflects the high degree of maturity of the sandsized material (Ronov et al., 1963).

Titanium is associated with aluminum (Figure 5); the ratio ranges from 0.040 to 0.060 and averages 0.050 , which corresponds to the $\mathrm{TiO}_{2} / \mathrm{Al}_{2} \mathrm{O}_{3}$ ratio of clays in the sedimentary rocks of the continents (Migdisov, 1960; Ronov and Yaroshevsky, 1976). The increase in the ratio in the Tithonian is due to grading of the sandy material in turbidites, which is evidently responsible for the accumulation, together with quartz grains, of the titanium minerals proper.

Carbonate-free samples generally contain 6 to 8 per cent total iron expressed as $\mathrm{Fe}_{2} \mathrm{O}_{3}$, the Lower Cretaceous being higher in iron than the overlying ones (Site 416 , Figure 6). The quantity of ferric oxide is generally 2 to 5 times that of ferrous oxide. ${ }^{1}$ The proportion of ferrous iron is relatively high in the lower Hauterivian and Valanginian (Site 416); some values of $\mathrm{Fe}_{2} \mathrm{O}_{3} / \mathrm{FeO}$ are less than unity in this interval. The oxidation state of iron is unrelated to the amount of organic carbon in these rocks.

Figure 7 is a plot of $\mathrm{Al}_{2} \mathrm{O}_{3} / \mathrm{SiO}_{2}$ against $\mathrm{Fe}_{2} \mathrm{O}_{3} / \mathrm{FeO}$ and gives an idea of the relationships among terrigenous and other sources of iron. Addition to pelitic terrigenous material of a constituent known to be rich in silica and ferric oxide (biogenic silica, authigenic clays, iron hydroxides) results in a generally higher oxidation state of iron and in a decrease in the alumina-silica ratio. This causes the inverse correlation between $\mathrm{Al}_{2} \mathrm{O}_{3} / \mathrm{SiO}_{2}$ and $\mathrm{Fe}_{2} \mathrm{O}_{3} / \mathrm{FeO}$ in most samples.

Figure 7 shows that points which represent Lower Cretaceous deposits are clustered in the lower right part of the main field of points; those of the Cenozoic are clustered in its upper left part. This suggests an increase in the contribution of non-terrigenous iron in the transition from Lower Cretaceous to Cenozoic deposits. The points lying below the lower regression line represent rocks in which the addition of diagenetic ferrous oxide is important; such rocks are not abundant among the samples. Above the upper regression line, rocks with ferric oxide are also scarce. A relatively high contribution of terrigenous iron is manifest in the fact that iron does not accumulate with respect to aluminum; the $\mathrm{Fe} / \mathrm{Al}$ ratio ranges from 0.5 to 0.7 in the studied rocks.

Nevertheless, we maintain that the proportion of non-terrigenous iron is somewhat greater in the Cenozoic and Upper Cretaceous than in the Lower Cretaceous, as shown by the $\mathrm{Fe} / \mathrm{Al}$ ratios. $\mathrm{An} \mathrm{Fe} / \mathrm{Al}$ ratio greater than unity was encountered only in two samples with maximum carbonate content. The content of manganese is higher here too; it is elsewhere low and similar to that in the terrigenous deposits of miogeosynclines (Ronov et al., 1965).

The alkali content of the samples varied differently. In carbonate-free samples, $\mathrm{K}_{2} \mathrm{O}$ amounts generally to only from 1 to 1.5 per cent at Site 415 from the upper Albian through the Paleocene; $\mathrm{K}_{2} \mathrm{O}$ increases to 4 per cent in the Quaternary deposits. In the deposits of Site

1 The values of ferric oxide given in Table 3 may be somewhat overstated, and that of ferrous oxide understated, because ferrous oxide does not include iron of pyrite, which has not been determined in most samples, and ferric oxide was obtained as the difference between total iron and ferrous iron. 


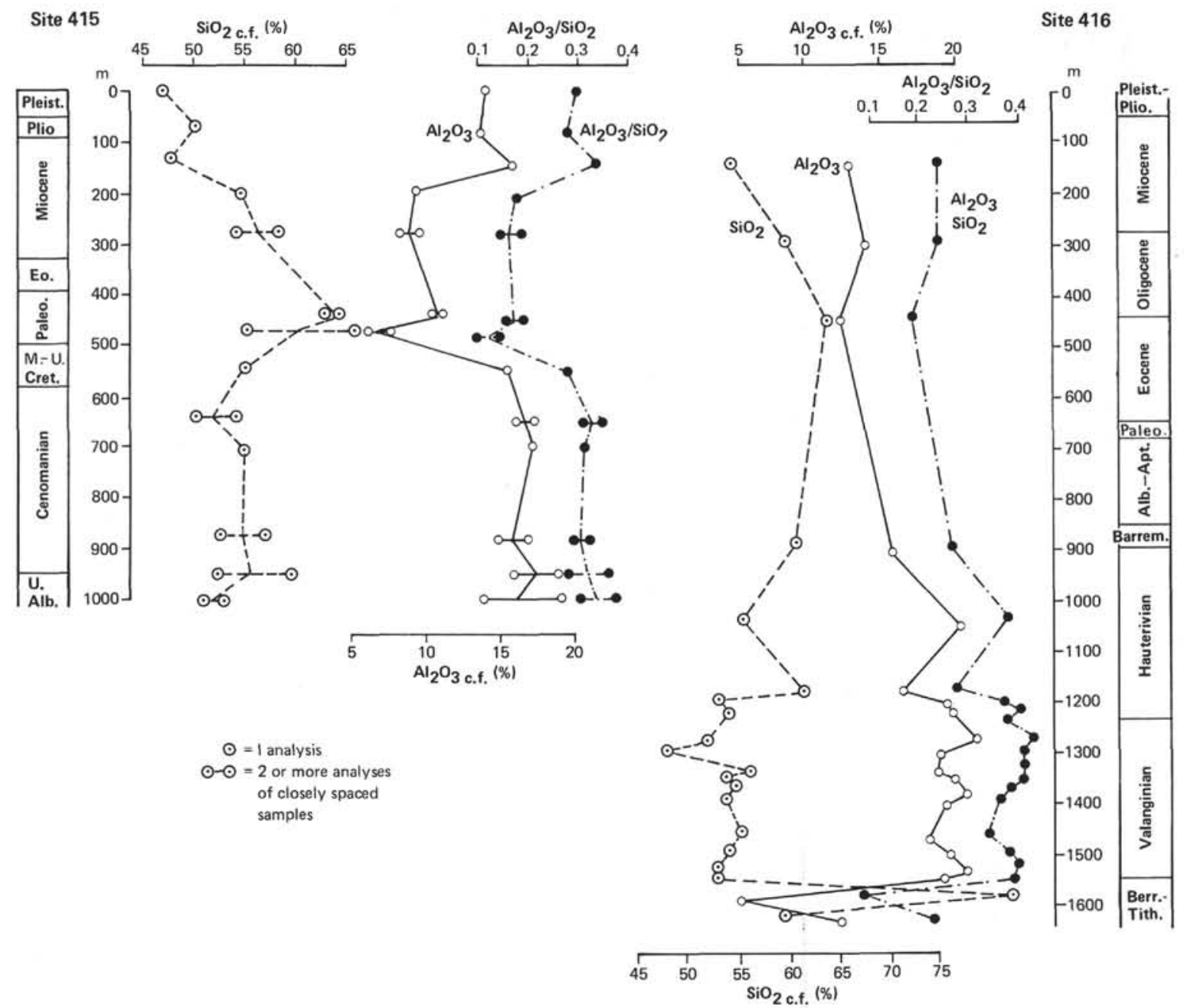

Figure 3. Distribution of $\mathrm{SiO}_{2}, \mathrm{Al}_{2} \mathrm{O}_{3}, \mathrm{Al}_{2} \mathrm{O}_{3} / \mathrm{SiO}_{2}$, calculated on the basis of carbonate-free samples, Sites 415 and 416.

416 , the $\mathrm{K}_{2} \mathrm{O}$ content is throughout rather high, from 3 to 4 per cent.

The observed increase in sodium content toward the upper horizons of Sites 415 and 416 can be accounted for, to a considerable extent, by the addition of salts derived from interstitial waters.

The rocks contain, as a rule, 0.2 to 0.5 per cent organic carbon and 0.2 to 0.4 per cent $\mathrm{P}_{2} \mathrm{O}_{5}$, calculated on the basis of carbonate-free samples. The maximum concentrations of these elements in carbonate-free samples exceed 1 per cent. Organic-carbon content is higher in the Cenozoic than in the older deposits. Phosphorus and opaline silica are at a maximum in the Paleocene through the lower Miocene (Site 415).

\section{DISTRIBUTION OF MINOR ELEMENTS} 6.

Minor-element analyses are presented in Tables 5 and

The studied elements can be grouped according to similarities in their distributions in the sections. Copper and zinc behave similarly; they exhibit an association with phosphorus in the Cenozoic and the absence of such an association in the Lower Cretaceous turbidites.
Maximum copper and zinc concentrations are found in the Cenozoic rocks, which are relatively rich in phosphate (Figures 4 and 8 ).

Of the minor elements, only zinc is associated with organic carbon and carbonate content, in the Cenozoic deposits. Because organic matter, phosphate, and carbonate in the studied sediments are biogenic, that biogenic processes have supplied the minor elements, particularly zinc in the Cenozoic sediments, is quite obvious. A selective accumulation of zinc by the carbonate skeletons of protozoans has been noted by Bostrom et al. (1973), and concentration of zinc by plankton has been described by Martin and Knauer (1973). Copper concentration shows a greater dependence on the oxidation state of iron than on zinc concentration. In the turbidites of the Lower Cretaceous, there is no correlation of both copper or zinc with biogenic components, which suggests an association of minor elements with terrigenous material here.

Molybdenum concentration is controlled by concentration of organic matter in the Cenozoic (Figure 9) and Upper Cretaceous; apparently, this organic matter is of marine origin. Molybdenum is unrelated to allogenic 


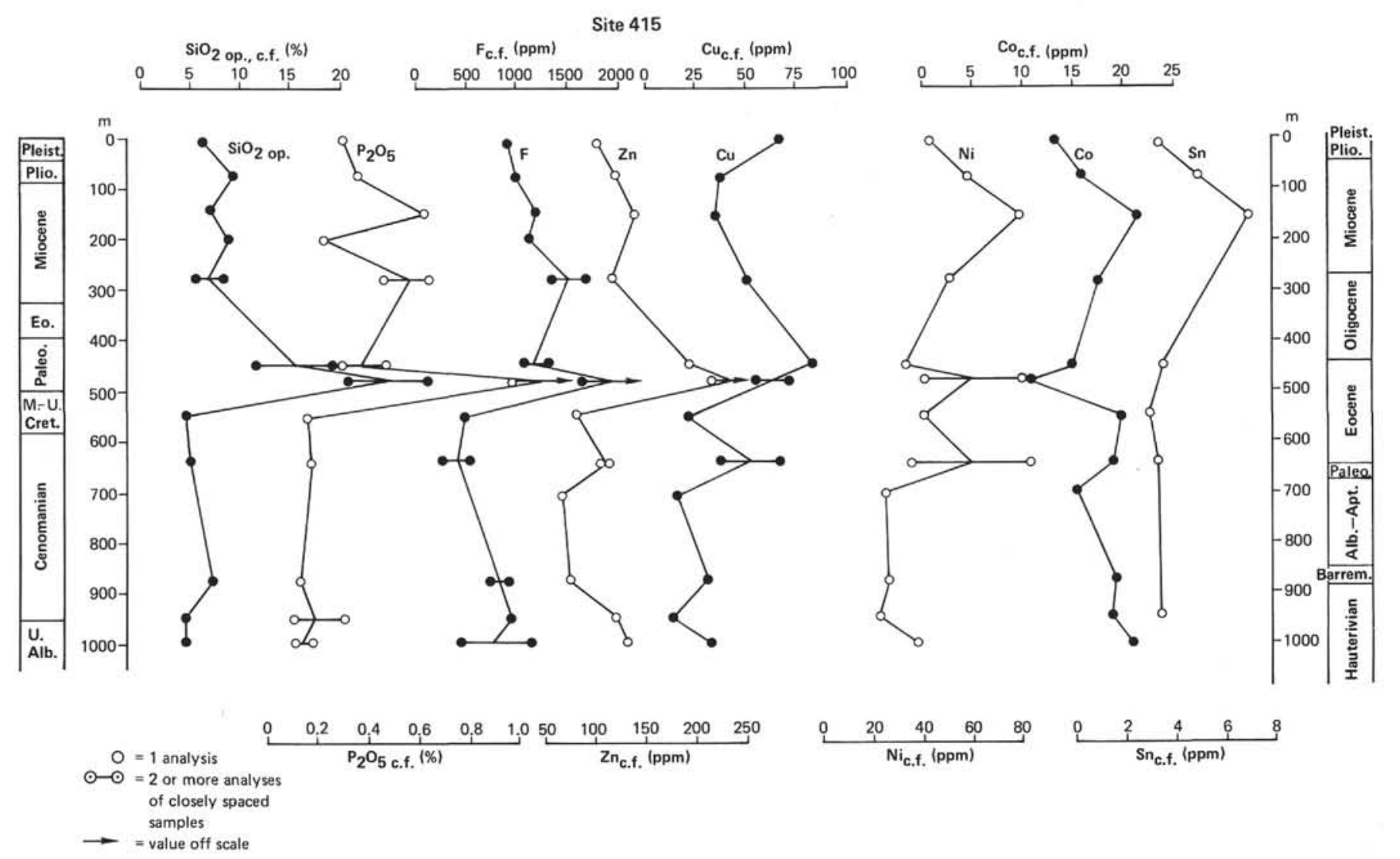

Figure 4. Distribution of opaline silica, phosphorus, fluorine, copper, zinc, nickel, cobalt, and tin, calculated on the basis of carbonate-free samples, Site 415.

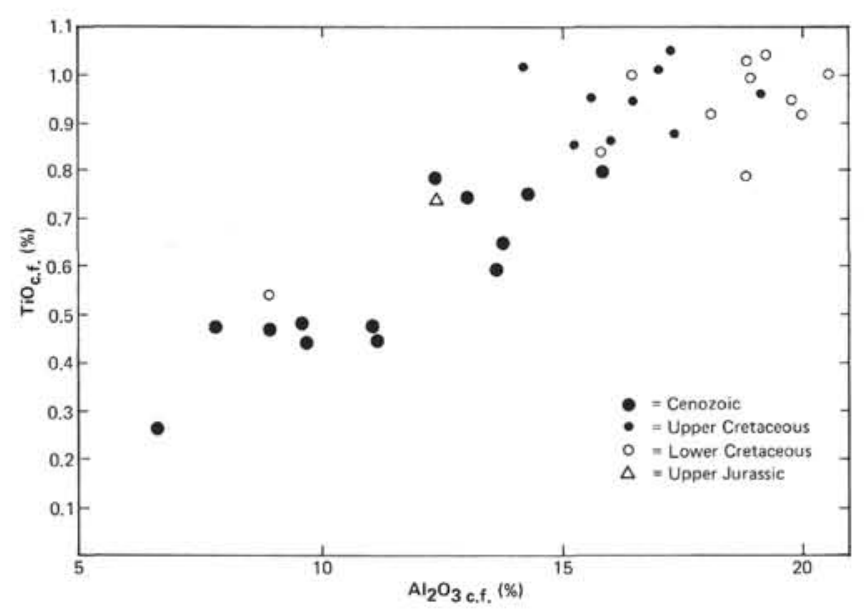

Figure 5. Variation of $\mathrm{TiO}_{2}$ content as a function of $\mathrm{Al}_{2} \mathrm{O}_{3}$ content, calculated on the basis of carbonatefree samples, Sites 415 and 416.

organic material which was supplied intensively from the continent during the Early Cretaceous. Similarly, the Lower Cretaceous and overlying deposits show a conspicuous difference in molybdenum content and oxidation state of iron: these values display an inverse dependence in the Cenozoic and Upper Cretaceous, whereas in the Lower Cretaceous the dependence is direct. Such a difference in the correlations of elements in these two groups of sediments is characteristic and suggests that the Cenozoic and Upper Cretaceous deposits are more autochthonous than the Lower Cretaceous deposits, which are essentially turbidites.

Nickel and cobalt exhibit some similarity in their variations (Site 415, Figure 4). Cobalt is associated with Aluminum (Figure 10) and iron in deposits of all ages. Among the metals under consideration, cobalt is most closely associated with terrigenous clay minerals. Nickel content in the carbonate-free samples of the Cenozoic (Figure 11) and Upper Cretaceous increases with the carbonate content of the natural sediment, which indicates the importance of non-terrigenous nickel in the younger deposits. The nickel-tin association (Figure 12) is quite unexpected.

The dependence of tin content on phosphorus content in the Cenozoic (and, probably, in the Upper Cretaceous) deposits, but not in the Lower Cretaceous, is interesting (Figure 13); in the Lower Cretaceous the correlation between these elements is inverse. Tin also shows a correlation with aluminum and potassium contents, which reflects the essential role of the terrigenous component in the distribution of tin. The correlation between tin content and $\mathrm{Al}_{2} \mathrm{O}_{3}$ content is stronger in the Cenozoic than in the Cretaceous. This conclusion is strengthened by the fact that both tin and nickel, besides their terrigenous components contained in silicates, have a non-terrigenous component which is detectable only in the younger deposits. 

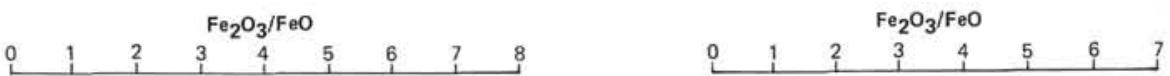

Site 416
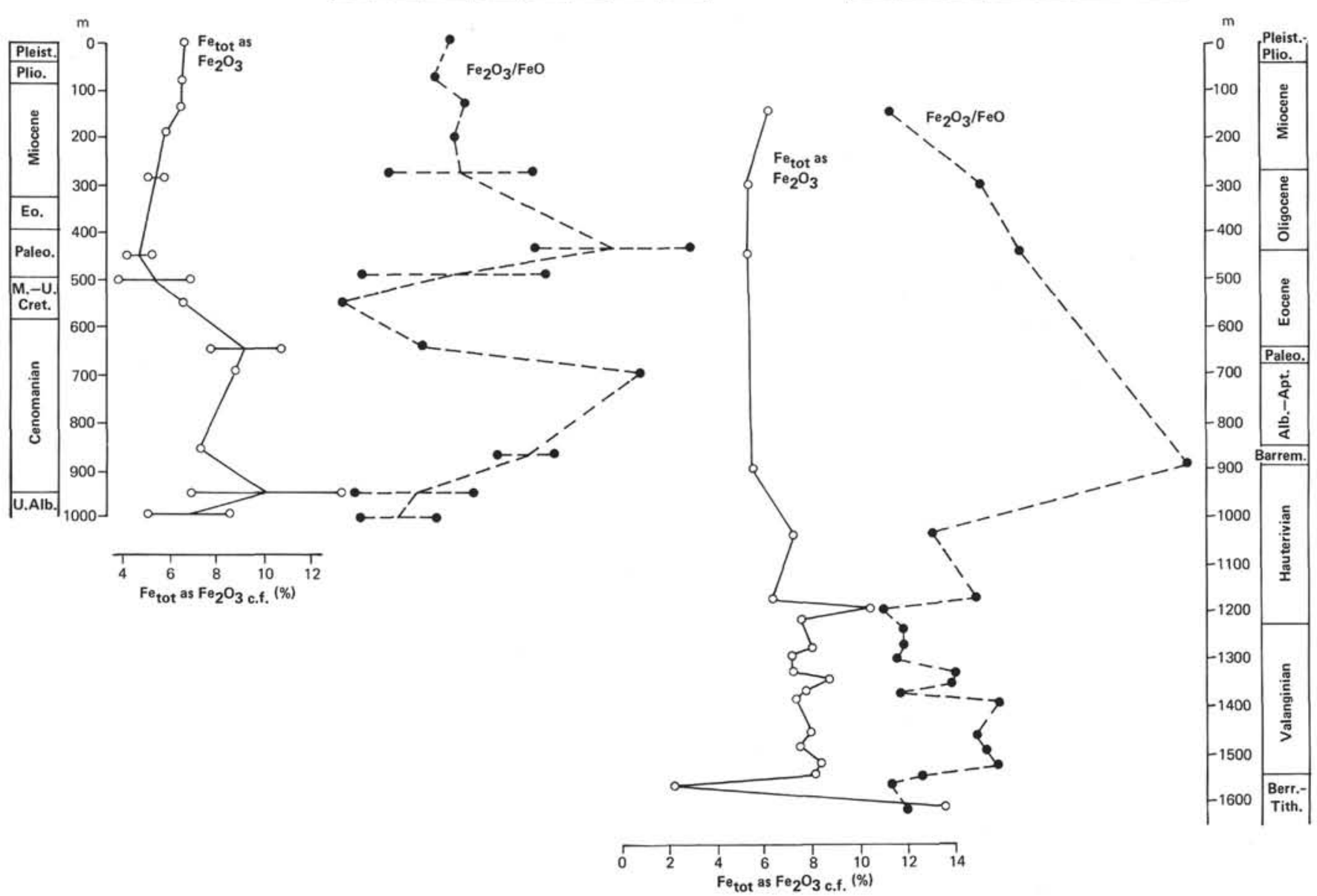

Figure 6. Distribution of total iron expressed as $\mathrm{Fe}_{2} \mathrm{O}_{3}$ and $\mathrm{Fe}_{2} \mathrm{O}_{3} / \mathrm{FeO}$, calculated on the basis of carbonate-free samples, Sites 415 and 416.

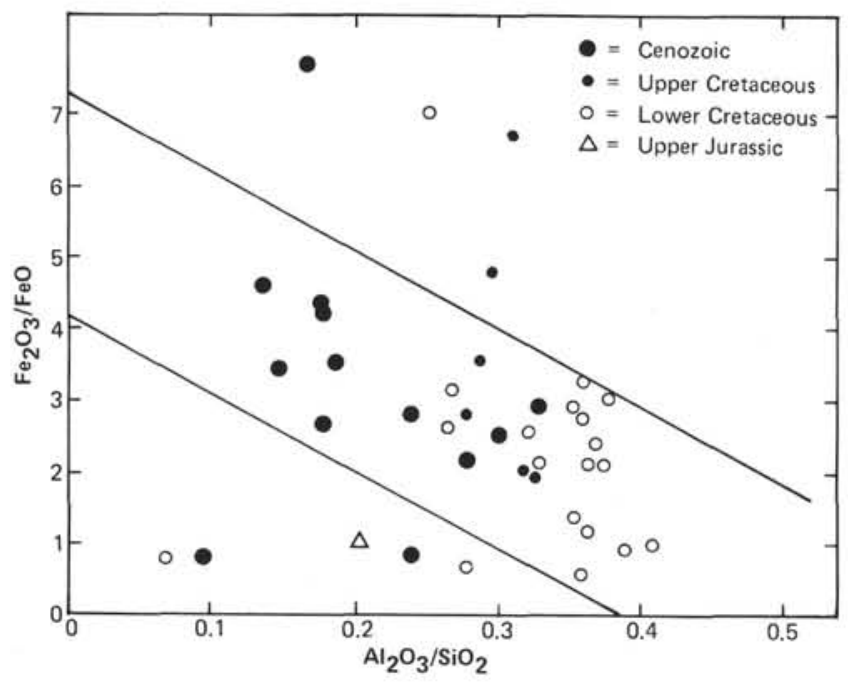

Figure 7. Variation of $\mathrm{Fe}_{2} \mathrm{O}_{3} / \mathrm{FeO}$ as a function of $\mathrm{Al}_{2} \mathrm{O}_{3} /$ $\mathrm{SiO}_{2}$, Sites 415 and 416 .
Variations in $\mathrm{P}_{2} \mathrm{O}_{5}$ and organic-carbon contents are not paralleled by variations in uranium content. In the studied samples, uranium generally varies with thorium. $\mathrm{The} \mathrm{Th} / \mathrm{U}$ ratio varies inversely with the carbonate content of the sediments, emphasizing the non-terrigenous nature of uranium and the terrigenous nature of thorium (Figure 14).

In the Upper Cretaceous and Cenozoic, fluorine is mainly in calcium phosphate (Figure 15), whereas in the Lower Cretaceous turbidites it is mainly in phyllosilicates. Another lithophile element, lithium, is also included in the lattice of clay minerals, which can be seen from its correlation with aluminum in the carbonatefree samples (Figure 16). However, lithium also shows evidence of a non-terrigenous admixture in the Cenozoic, where its concentration relative to $\mathrm{Al}_{2} \mathrm{O}_{3}$ content is higher than in the Lower Cretaceous.

The rubidium content closely parallels the potassium content (Figure 17). The $\mathrm{K} / \mathrm{Rb}$ ratio varies within a narrow range (160 to 240 ) and shows almost no dependence on the age of the sediments. 
TABLE 5

Minor-Element Analyses (ppm), Site 415

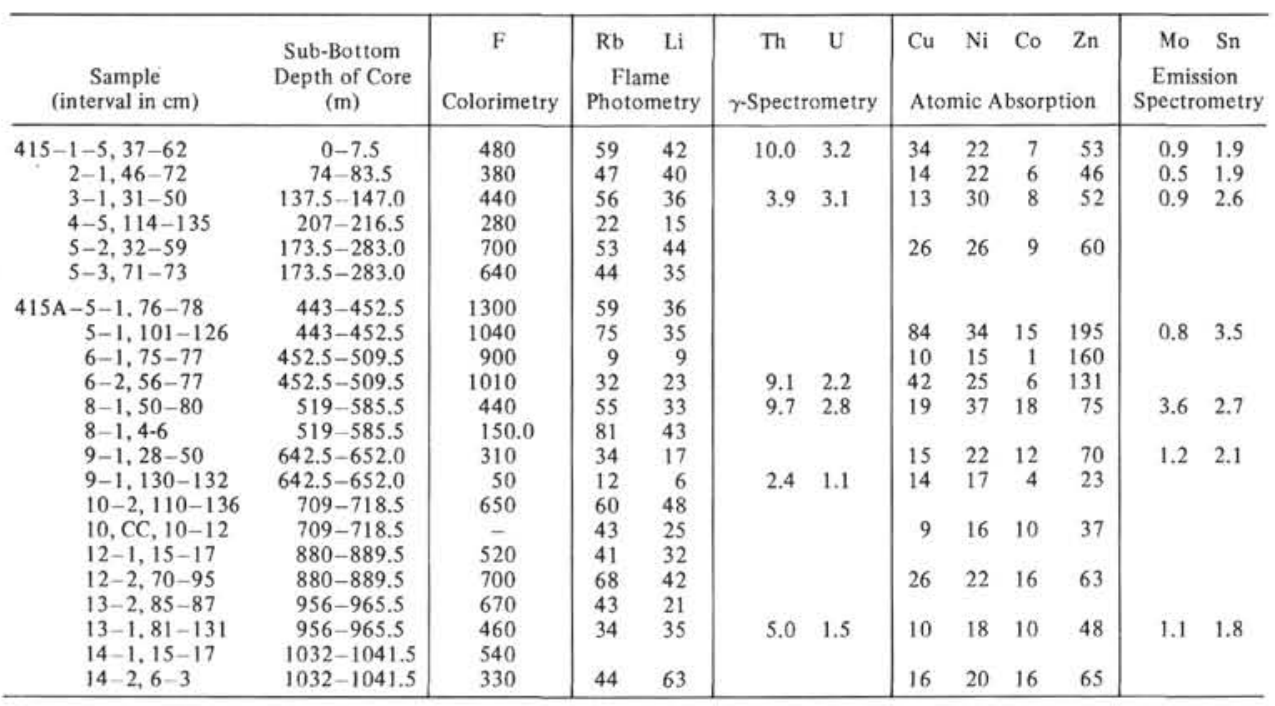

TABLE 6

Minor-Element Analyses (ppm), Site 416

\begin{tabular}{|c|c|c|c|c|c|c|c|c|c|c|c|c|}
\hline $\begin{array}{c}\text { Sample } \\
\text { (interval in } \mathrm{cm} \text { ) }\end{array}$ & $\begin{array}{l}\text { Sub-Bottom } \\
\text { Depth of Core } \\
\text { (m) }\end{array}$ & Colorimetry & $\begin{array}{l}\mathrm{Rb} \\
\text { Fla } \\
\text { Photc }\end{array}$ & $\begin{array}{l}\mathrm{Li} \\
\text { me } \\
\text { metry }\end{array}$ & $\begin{array}{c}\text { Th } \\
\gamma \text {-Spectr }\end{array}$ & ometry & $\begin{array}{l}\mathrm{Cu} \\
\text { Ator }\end{array}$ & $\mathrm{Ni}$ & Co & $\mathrm{Zn}$ & $\begin{array}{c}\text { Mo } \\
\text { Emiss } \\
\text { Spectro }\end{array}$ & $\begin{array}{l}\text { Sn } \\
\text { sion } \\
\text { ometry }\end{array}$ \\
\hline $416-1-1,115-140$ & $146-155.5$ & 750 & 86 & 58 & 6.3 & 2.2 & 15 & 25 & 10 & 53 & 0.8 & 2.2 \\
\hline $2-2,56-74$ & $298-304.5$ & 860 & 87 & 68 & 6.1 & 2.3 & 56 & 17 & & 98 & 1.1 & 3.5 \\
\hline $3-1,72-76$ & $450-459.5$ & 880 & 91 & 46 & 6.3 & 2.1 & 32 & 28 & 12 & 75 & & \\
\hline $3-3,60-87$ & $450-459.5$ & 1010 & 92 & 57 & & & 39 & 33 & 14 & 90 & 1.7 & 2.8 \\
\hline $6-3,29-75$ & $887-896.5$ & 1480 & 159 & 55 & & & 100 & 40 & 16 & 125 & 0.6 & 3.1 \\
\hline $7-2,36-47$ & $991.5-1093.0$ & 450 & 155 & 103 & & & 39 & 35 & 17 & 94 & 0.6 & 3.5 \\
\hline $9-3,114-117$ & $1176.9-1185.4$ & - & 106 & 65 & 8.7 & 1.6 & & & 12 & & 0.7 & 4.0 \\
\hline $11-4,61-81$ & $1194.8-1204.3$ & 490 & 144 & 115 & & & & & & & 0.4 & 3.7 \\
\hline $13-2,79-100$ & $1213.8-1222.4$ & 900 & & & & & & & & & & \\
\hline $15-1,64-100$ & $1232.9-1242.5$ & & 137 & 82 & & & 36 & 42 & 18 & 81 & 0.7 & 4.2 \\
\hline $20-2,0-50$ & $1277.5-1287.0$ & 430 & 171 & 95 & - & & 42 & 34 & 17 & 68 & 0.9 & 4.9 \\
\hline $22-3,68-86$ & $1299.5-1309.1$ & 770 & 149 & 80 & & & & & & & & \\
\hline $27-1,68-118$ & $1346-1356$ & 720 & 170 & 90 & 12.7 & 2.9 & 56 & 36 & 20 & 90 & 0.8 & 3.4 \\
\hline $25-1,6-60$ & $1327.7-1336.7$ & 920 & & & & & 42 & 39 & 22 & 98 & & \\
\hline $29-2,10-40$ & $1365.7-1375.2$ & 1010 & 183 & 86 & & & & & & & & \\
\hline $31-4,32-74$ & $1384.6-1394.1$ & 960 & 196 & 75 & & & 48 & 65 & 22 & 160 & 1.1 & 4.5 \\
\hline $40-3,95-125$ & $1454.5-1463.9$ & 890 & 119 & 55 & & & 26 & 33 & & 64 & 0.8 & 2.9 \\
\hline $44-2,57-91$ & $1491.9-1501.2$ & 810 & 167 & 69 & 10.9 & 2.1 & 52 & 33 & 21 & 93 & 1.1 & 3.0 \\
\hline $47-2,108-150$ & $1520-1529.5$ & 490 & 131 & 85 & & & & & & & & \\
\hline $50-2,31-81$ & $1548.6-1558$ & 920 & 153 & 75 & & & 33 & 58 & 25 & 84 & 1.9 & 3.8 \\
\hline $52-2,14-16$ & $1567.4-1576.8$ & 260 & 36 & 18 & 4.0 & 1.5 & 10 & 9 & 5 & 119 & 0.4 & 1.4 \\
\hline $57-1,64-72$ & $1614.5-1624.0$ & - & 17 & 10 & 1.4 & 1.4 & 5 & 6 & 2 & 25 & 0.5 & \\
\hline
\end{tabular}

\section{DISTRIBUTION OF SULFUR ISOTOPES}

The distribution of sulfur isotopes is summarized in Table 7. The $\delta^{34} \mathrm{~S}$ values of sulfide (pyrite) sulfur vary at both sites over a wide range, from -42.0 to -0.9 per mill (Table 7). These variations are by no means random: there is an increase in $\delta^{34} \mathrm{~S}$ values with depth at both sites. The sulfur isotopes change at Site $\mathbf{4 1 5}$ more abruptly; the $\delta^{34} \mathrm{~S}$ values in the Miocene change here from -41.9 to -9.1 per mill, varying further within the range -12.1 to -0.9 per mill. At Site 416 , the values change more gradually: from -39.7 per mill in the Miocene to -2.7 and -6.4 per mill in the Berriasian.

It should be noted that the variations of sulfur isotopes show no accumulation of the heavy isotope in sulfates of interstitial waters. Thus, in Sample 415-5-2, $32-59 \mathrm{~cm}$, Site 415 , where $\delta^{34} \mathrm{~S}_{\text {pyr }}$ is -9.1 per mill (as compared to -41.9 per mill in the previous sample), the isotopic composition of the water extract remains close to that of sea-water sulfate. Sulfate from the Lower Cretaceous of the same site (Sample 415A-14-2, 3-6 cm) proved to be enriched in ${ }^{32} \mathrm{~S}\left(\delta^{34} \mathrm{~S}=+1.2\right.$ per mill) compared to sulfate of modern sea water. These data, the long span of geological time over which the isotopically light sulfides show no changes (Miocene to Quaternary, or about 24 to 30 m.y.), and, finally, the overall large variations in $\delta^{34} \mathrm{~S}$ of sedimentary sulfides at the two sites suggest that the observed trends are, most likely, caused by the changes in the nature of sedimentation during the Mesozoic and Cenozoic instead of by diagenetic processes.

The probability of a difference in the conditions of sulfate reduction in deposits of different ages at Sites 415 and 416 is strengthened by the correlation between 


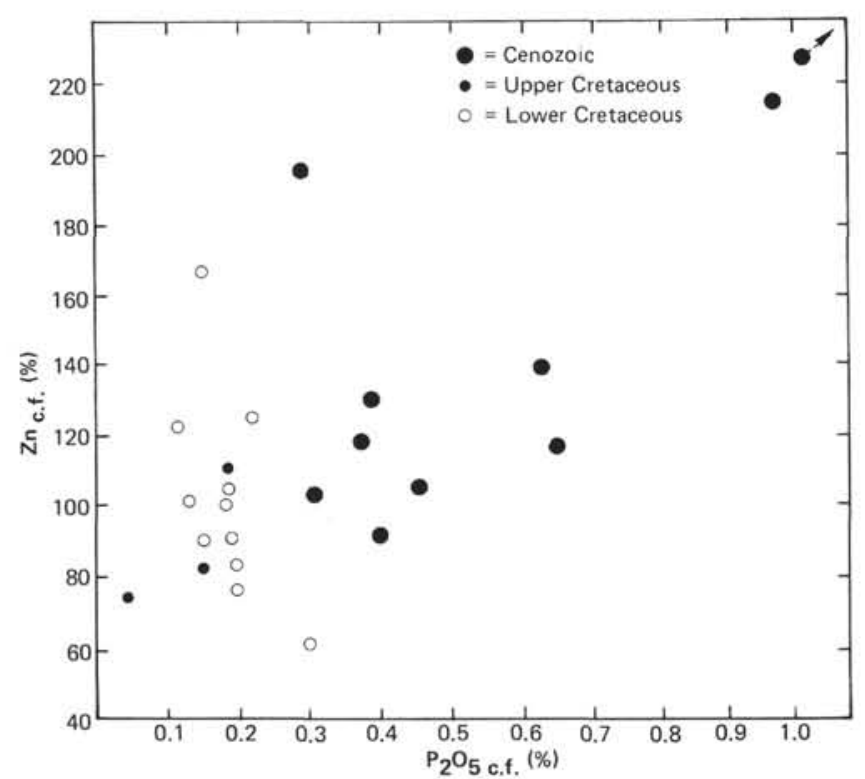

Figure 8. Variation of zinc content as a function of $\mathrm{P}_{2} \mathrm{O}_{5}$ content, calculated on the basis of carbonatefree samples, Sites 415 and 416.

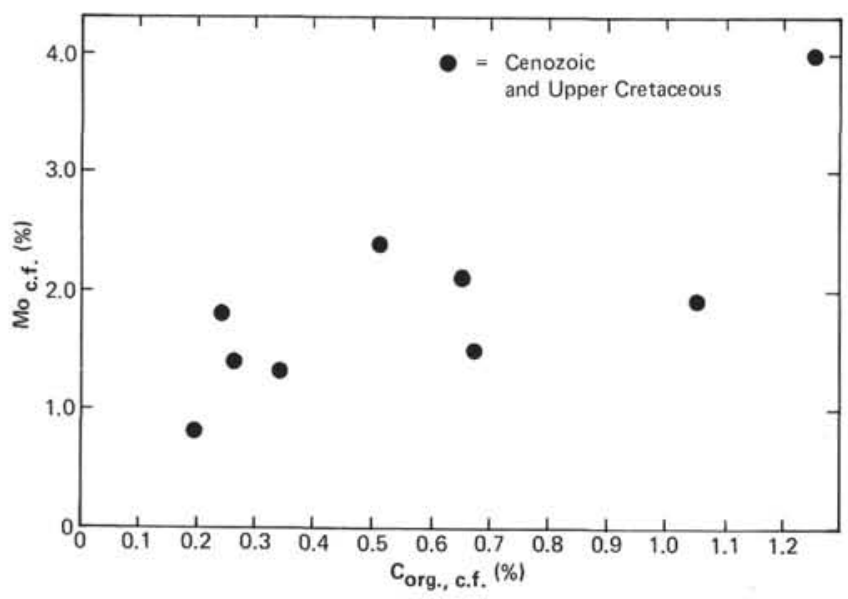

Figure 9. Variation of molybdenum content as a function of organic-carbon content, calculated on the basis of carbonate-free samples, Sites 415 and 416.

the $\delta^{34} \mathrm{~S}$ values for sulfides and the organic-carbon content. The youngest sediments at both sites (Miocene to Quaternary) show the isotopically lightest pyrite sulfur, the content of organic matter being comparatively insignificant (Figure 18a); this is also observed in recent pelagic sediments (Figure 18b). The older Cenozoic (and, probably, Upper Cretaceous) deposits exhibit accumulation of the light sulfur isotope in sulfides, paralleling an increase in organic carbon.

The Lower Cretaceous sediments, on the contrary, are characterized by accumulation of the heavy sulfur isotope in sulfides with increased concentration of organic carbon (Figure 19a). Such correlations are normally characteristic of deposits of the hyposaline continental basins (Figure 19b) or restricted marine basins

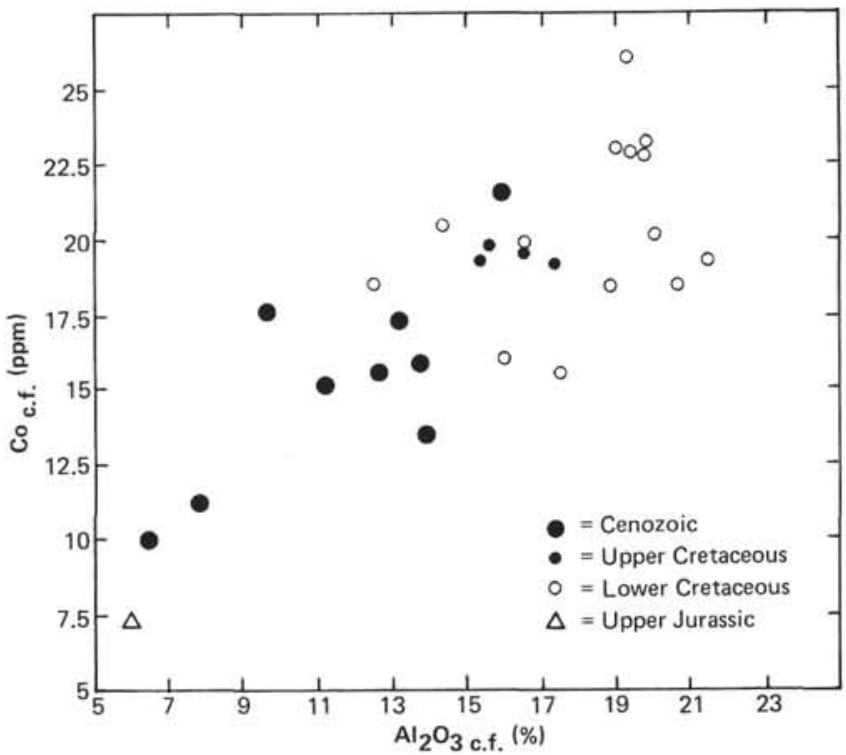

Figure 10. Variation of cobalt content as a function of $\mathrm{Al}_{2} \mathrm{O}_{3}$ content, calculated on the basis of carbonatefree samples, Sites 415 and 416.

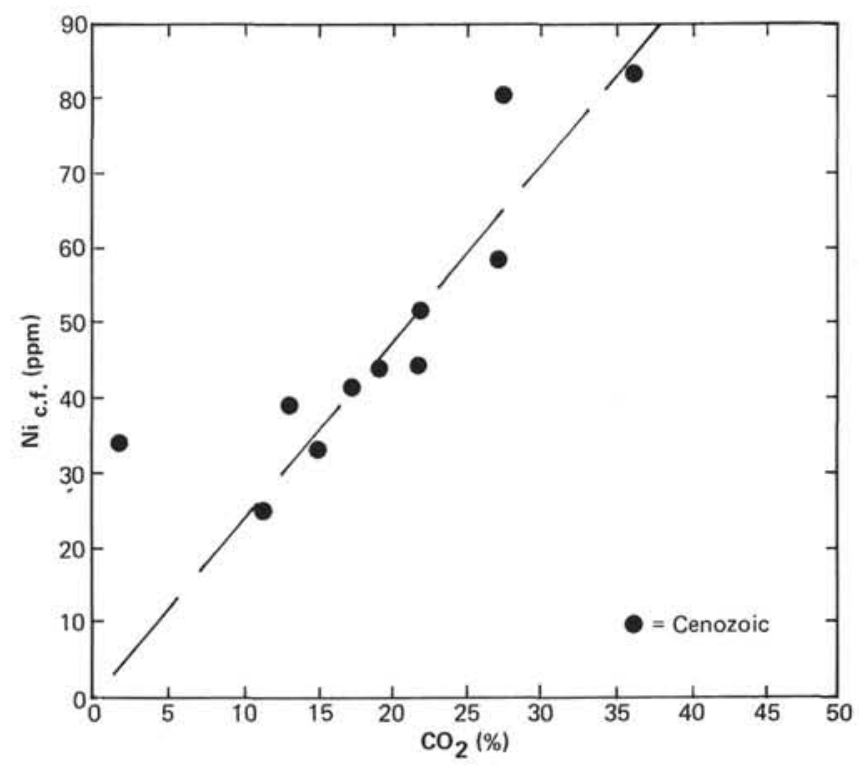

Figure 11. Variation of nickel content, calculated on the basis of carbonate-free samples, as a function of the carbonate content of the natural sediment, Sites 415 and 416.

(Migdisov et al., 1974). At any rate, according to the ratio of $\delta^{34} \mathrm{~S}$ to organic-carbon content, three groups of sediments can be distinguished which were probably formed under different conditions: Lower Cretaceous, Upper Cretaceous to Miocene, and Miocene to Quaternary. Finally, it should be pointed out that the difference in variations of $\delta^{34} \mathrm{~S}$ for pyrite sulfur at the same stratigraphic horizons at Sites 415 and 416 provides evidence for different conditions of sedimentation at the two sites during the Mesozoic and Cenozoic. 


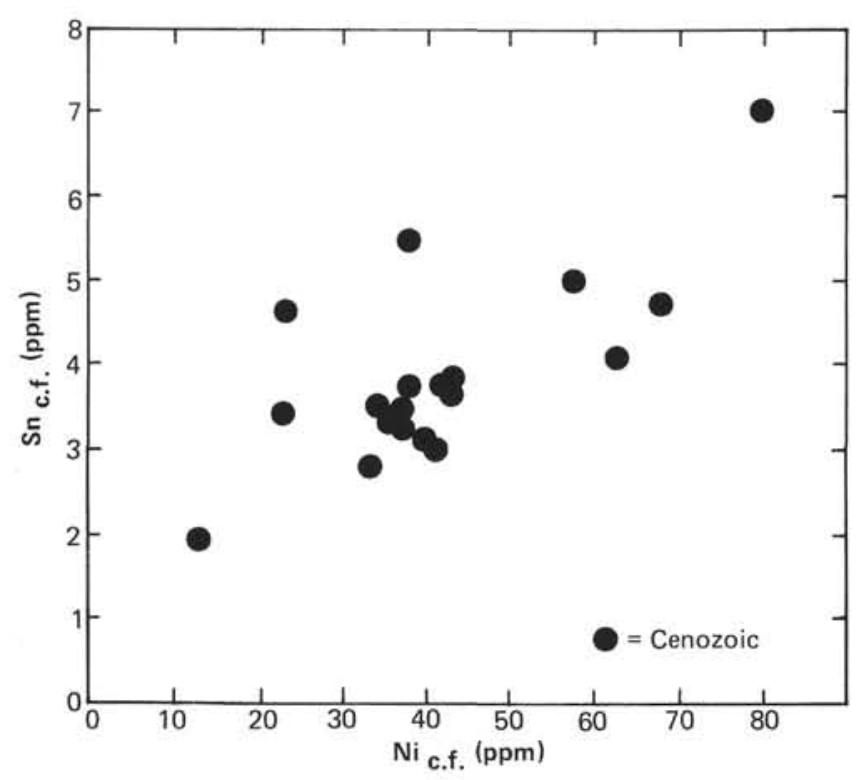

Figure 12. Variation of tin content as a function of nickel content, calculated on the basis of carbonatefree samples, Sites 415 and 416.

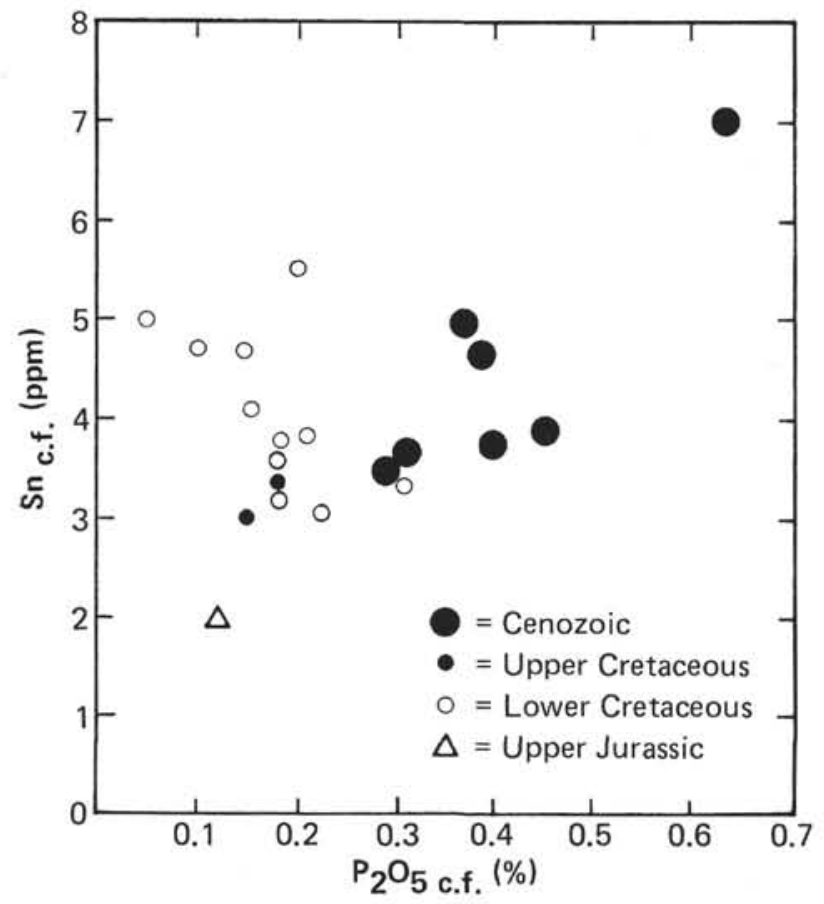

Figure 13. Variation of tin content as a function of $\mathrm{P}_{2} \mathrm{O}_{5}$ content, calculated on the basis of carbonatefree samples, Sites 415 and 416.

\section{FURTHER INTERPRETATION AND SUMMARY OF DATA}

The foregoing evidence indicates that there were two main sources of elements for the sediments of the Moroccan Basin, which differed in importance for different elements and for sediments of different age. Variations in the relative importance of the two major sources can be illustrated by the variations of the major chemical components at the two sites (Figure 3).

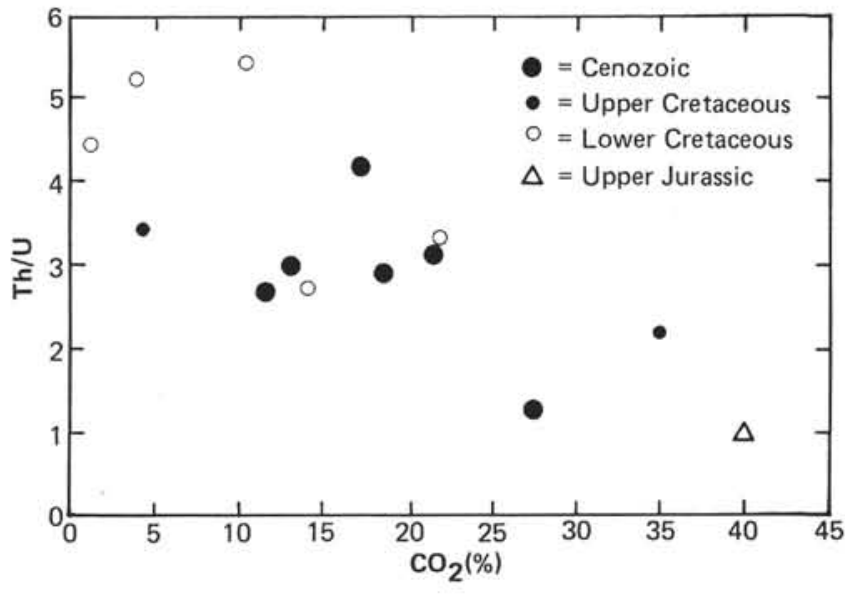

Figure 14. Variation of $T h / U$ as a function of carbonate content, Sites 415 and 416.

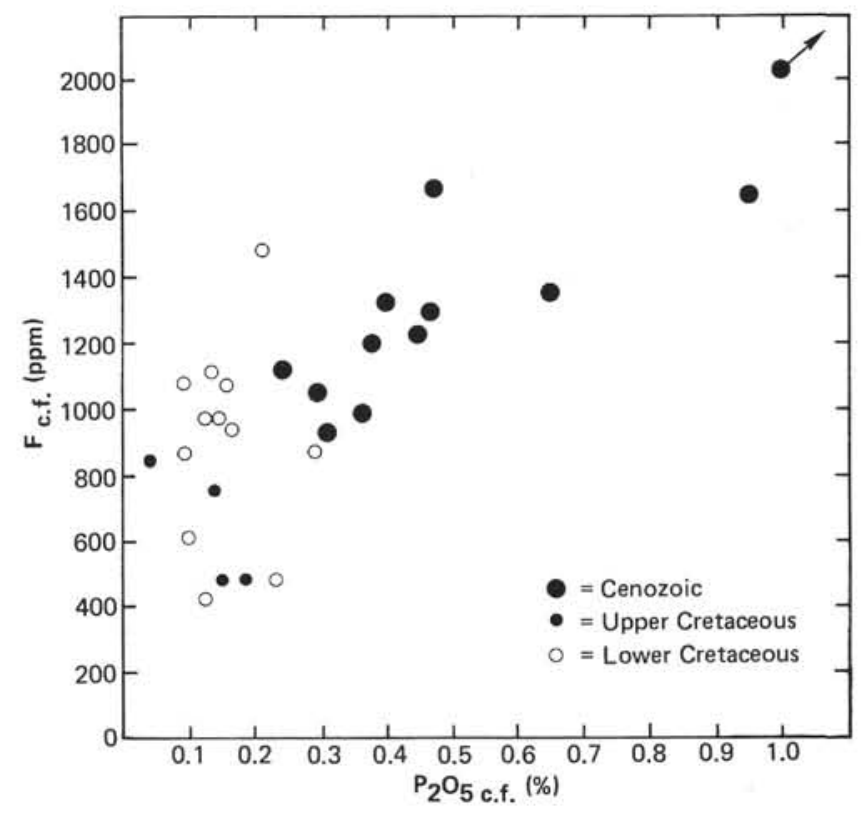

Figure 15. Variation of fluorine content as a function of $\mathrm{P}_{2} \mathrm{O}_{5}$ content, calculated on the basis of carbonate-free samples, Sites 415 and 416.

The first group accounts for aluminum and titanium, the most inert elements in the sedimentary cycle, which are usually indicative of terrigenous sediments (Migdisov, 1960; Strakhov, 1976; Böstrom, 1973). The contents of these elements calculated for silica- and carbonate-free samples show an upward decrease in the stratigraphic column, which suggests a reduction in the supply of pelitic material rich in these elements. This corresponds to a decrease in the rate of accumulation of silica- and carbonate-free material from the Valanginian to the present. Therefore, the Valanginian and Hauterivian sediments, which were rapidly buried and are little altered, must best reflect the composition of the continental source.

The chemical composition of the younger sediments shows the progressive effect of non-terrigenous sources. 


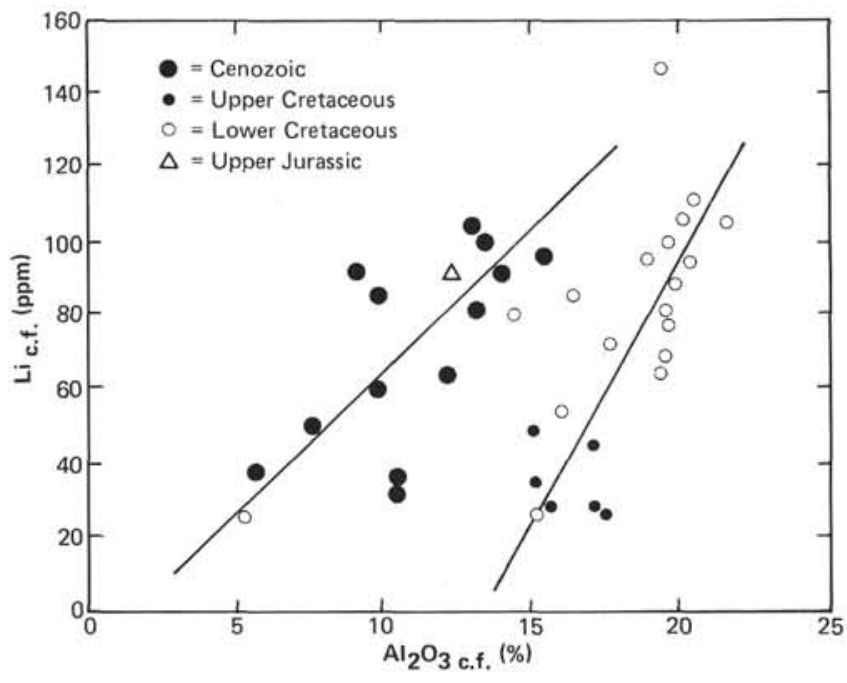

Figure 16. Variation of lithium content as a function of $\mathrm{Al}_{2} \mathrm{O}_{3}$ content, calculated on the basis of carbonatefree samples, Sites 415 and 416.

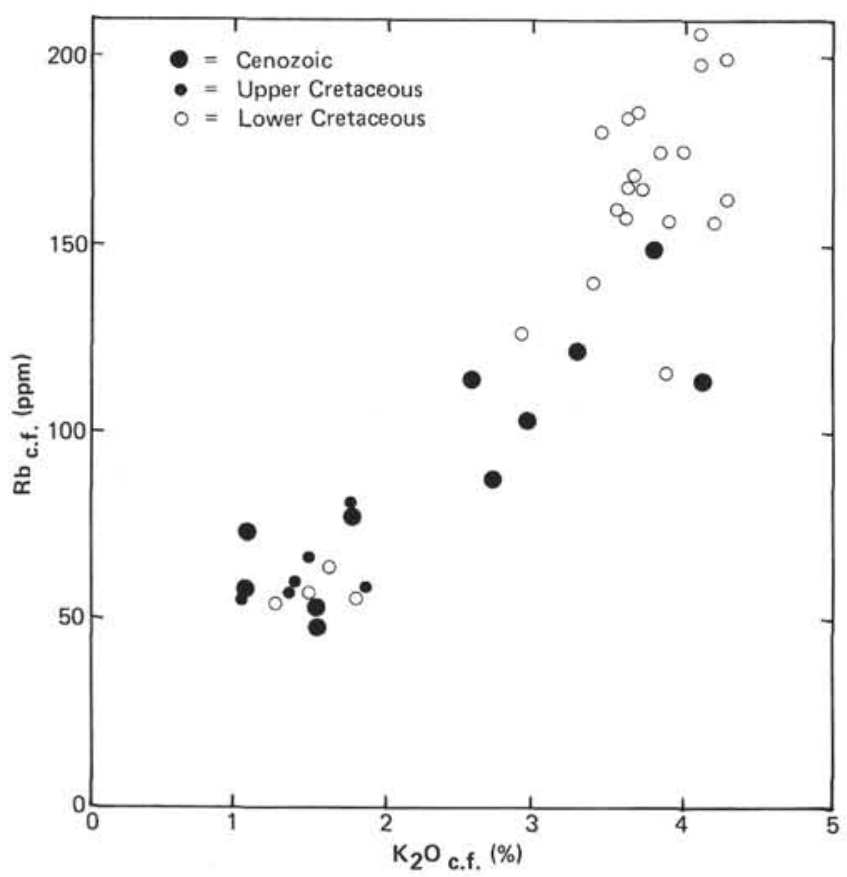

Figure 17. Variation of rubidium content as a function of $\mathrm{K}_{2} \mathrm{O}$ content, calculated on the basis of carbonatefree samples, Sites 415 and 416.

These are, first of all, biogenic sources which are the result of extraction of elements from sea water. These sources are reflected in variations of the content of $\mathrm{CO}_{2}$, opaline silica, and $\mathrm{P}_{2} \mathrm{O}_{5}$, which increase from the Lower Cretaceous to the Cenozoic. Accumulation of these components is facilitated by the decreased rates of supply of terrigenous material which are characteristic of pelagic sedimentation. In fact, these components show an inverse dependence on the accumulation rate of terrigenous material (Figure 20). The conspicuous enrichment of the Paleocene sediments in opaline silica and
TABLE 7

Distribution of Sulfur Isotopes, Sites 415 and 416

\begin{tabular}{|c|c|c|c|c|}
\hline $\begin{array}{c}\text { Sample } \\
\text { (interval in cm) }\end{array}$ & $\begin{array}{l}\text { Sub-Bottom } \\
\text { Depth of Core } \\
\text { (m) }\end{array}$ & $\mathrm{S}_{\mathrm{pyr}}(\%)$ & ${ }^{34} S_{p y r}(\%)$ & ${ }^{34} \mathrm{~S}_{\mathrm{SO}_{4}}(\%)$ \\
\hline $\begin{array}{r}415-2-1,46-72 \\
3-1,31-50 \\
5-2,32-59\end{array}$ & $\begin{array}{r}74-83.5 \\
137.5-147 \\
273.5-283\end{array}$ & $\begin{array}{l}0.142 \\
0.240\end{array}$ & $\begin{array}{r}-42.0 \\
-41.9 \\
-9.1\end{array}$ & +19.2 \\
\hline $\begin{array}{c}415 \mathrm{~A}-6-2,56-77 \\
8-1,50-80 \\
9-1,28-50 \\
10-2,110-136 \\
13-1,81-131 \\
14-2,3-6\end{array}$ & $\begin{array}{c}452.5-509.5 \\
519-585.5 \\
642.5-652 \\
709-718.5 \\
956-965.5 \\
1032-1041.5\end{array}$ & $\begin{array}{l}0.959 \\
0.746 \\
0.275\end{array}$ & $\begin{array}{r}-6.1 \\
-12.1 \\
-7.1 \\
-0.9 \\
-12.1 \\
-2.6\end{array}$ & +1.2 \\
\hline $\begin{array}{c}416 \mathrm{~A}-1-1,115-140 \\
2-2,56-74 \\
79-91 \\
3-3,60-87 \\
11-4,61-81 \\
15-1,64-100 \\
104-111 \\
143-150 \\
22-3,68-86 \\
25-1,6-60 \\
29-2,10-40 \\
31-4,32-74 \\
50-2,31-81 \\
52-2,14-16\end{array}$ & $\begin{array}{l}1232.9-1242.5 \\
1299.5-1309.1 \\
1327.7-1336.7 \\
1365.7-1375.2 \\
1384.6-1394.1 \\
1548.6-2558 \\
1567.4-1576.8\end{array}$ & $\begin{array}{l}0.326 \\
\\
0.461 \\
0.302 \\
0.272 \\
0.277 \\
0.144 \\
0.032\end{array}$ & $\begin{array}{l}-39.7 \\
-29.5 \\
-31.7 \\
-21.3 \\
-28.3 \\
-25.5 \\
-15.3 \\
-26.1 \\
-25.1 \\
-2.7 \\
-6.4\end{array}$ & \\
\hline
\end{tabular}

$\mathrm{P}_{2} \mathrm{O}_{5}$ is accompanied by accumulation of organic carbon. Such an explosion of biological activity can be seen near the modern continental coasts in areas of upwelling, but to prove a similar origin for the concentrations at the Mesozoic/Cenozoic boundary in the deposits of the Moroccan Basin it would be necessary to conduct special investigations.

The evidence discussed in the foregoing sections indicates that most of the studied elements are associated with $\mathrm{Al}_{2} \mathrm{O}_{3}$ or biogenic components in various degrees, which reflects the difference in terrigenous and nonterrigenous sources of these elements. It is noteworthy that the non-terrigenous contribution of iron and manganese, characteristic of pelagic mud, is strictly biogenic. The transition metals cobalt, nickel, zinc, and copper show different relationships to terrigenous and non-terrigenous sources. In all sediments, regardless of age, the most obvious association with terrigenous material can be detected in cobalt. An association of cobalt with biogenic components was not recorded even in the recent sediments. Copper proves to be more mobile, but its concentrations parallel those of a nonterrigenous component $\left(\mathrm{P}_{2} \mathrm{O}_{5}\right)$ only in the Cenozoic; in the Lower Cretaceous, it is markedly associated with terrigenous material.

In the Cenozoic, nickel content parallels carbonate content, another biogenic component; this phenomenon was not observed in the Lower Cretaceous. Finally, zinc concentrations in the Cenozoic parallel both the phosphate and carbonate components, while in the Lower Cretaceous this element, like nickel, appears to be associated only with the clay material.

The tendency of nickel to accumulate more than copper in the non-terrigenous material remains unexplained. Analyses of the carbonate skeletons of marine organisms (Böstrom et al., 1973; Martin and Knauer, 1973) reveal that the nickel content is much lower than the copper content. At the same time, the evidence shows rather convincingly that copper is confined more than 

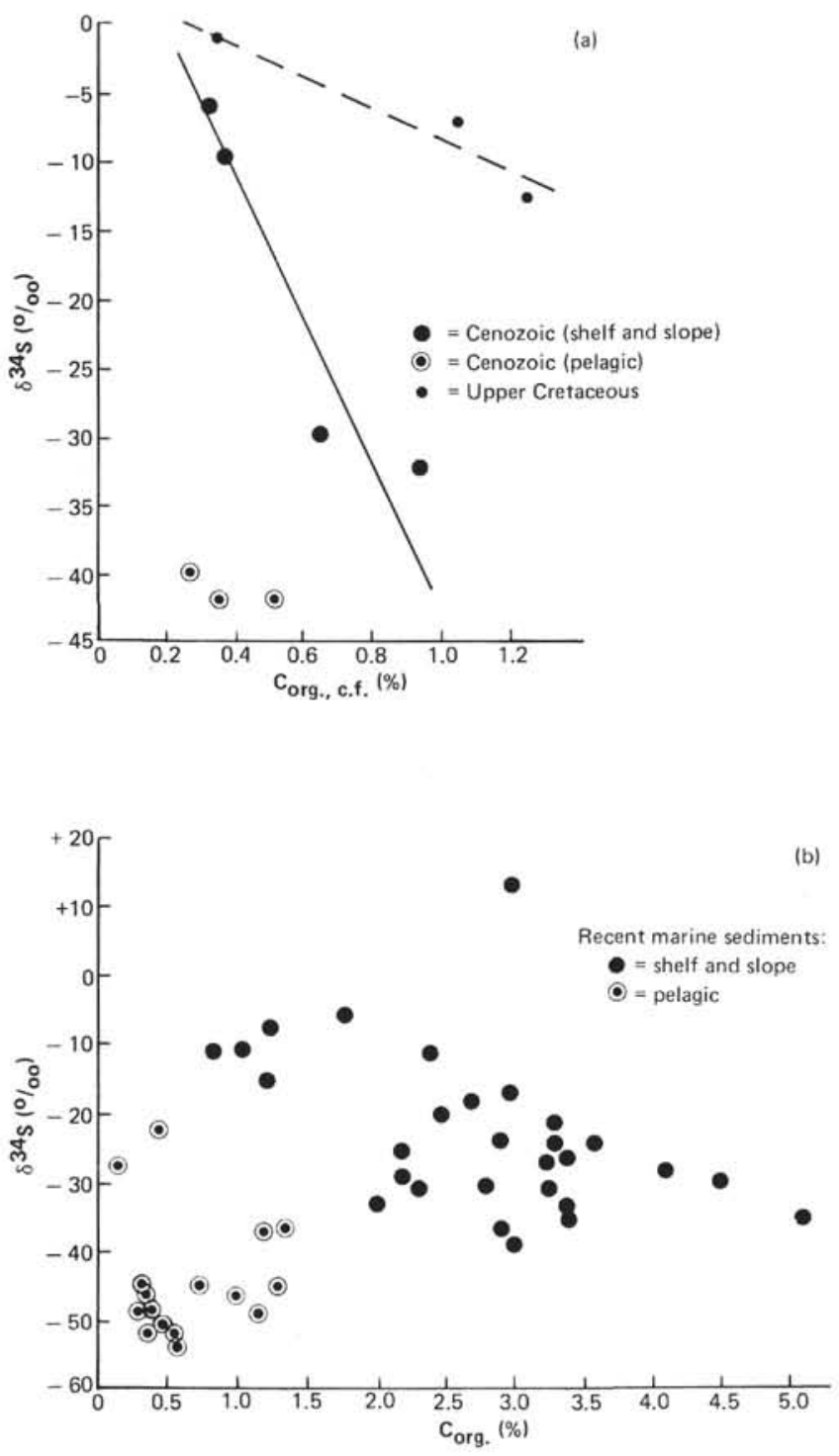

Figure 18. Variation of the isotopic composition of sulfide sulfur as a function of organic-carbon content, calculated on the basis of carbonate-free samples, Sites 415 and $416($ a), and comparative data for recent marine sediments (b).

nickel to the terrigenous material of the studied deposits.

In some cases, a non-terrigenous source is inferred for elements which are correlated with silicates. Thus, for example, lithium is correlated with aluminum (Horstman, 1957; Ronov et al., 1970) both in the Cretaceous and the Cenozoic, but more closely in the Cenozoic; the inference that the lithium is non-terrigenous is based on a version of the "terrigenous lattice" method (Strakhov, 1976; Böstrom, 1973), which allows a rough determination of the non-terrigenous sources of the material. Variations in the relationship between aluminum and other elements reveal that such a non-terrigenous source is essential for many elements $(\mathrm{Zn}, \mathrm{Ni}, \mathrm{Cu}$, $\mathrm{P}, \mathrm{Li}, \mathrm{Sn}, \mathrm{U}$, and $\mathrm{F}$ ) and the maximum non-terrigenous contribution corresponds to the explosion in biological
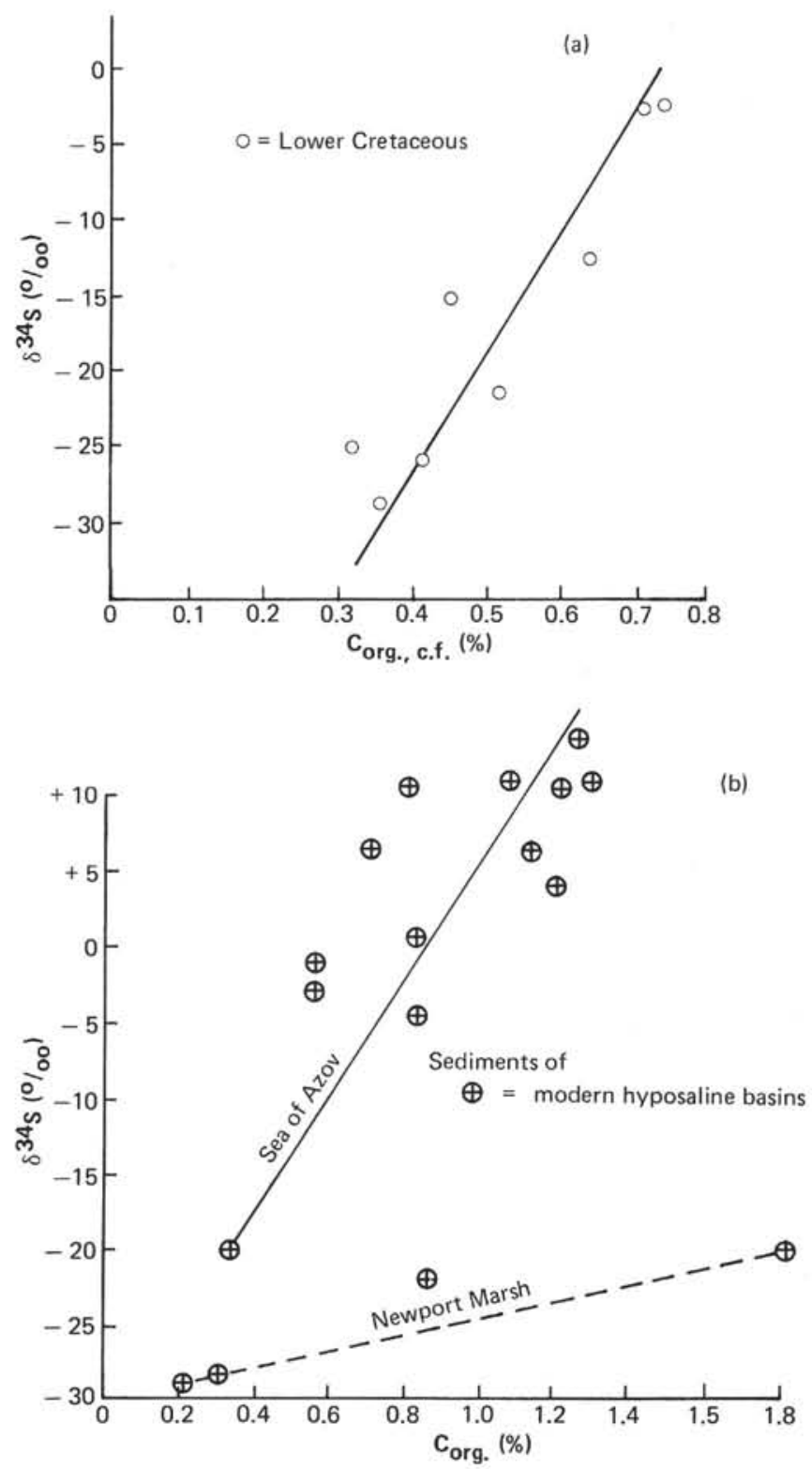

Figure 19. Variation of isotopic composition of sulfide sulfur as a function of organic-carbon content, calculated on the basis of carbonate-free samples, Sites 415 and 416 (a) and comparative data for modern hyposaline basins (b).

activity. Here also, a shift can be noted in element/aluminum ratios, from values characteristic of continental rocks to values typical of pelagic sediments. This shift is least conspicuous for cobalt and most conspicuous for zinc, which is in agreement with the foregoing evidence.

All the minor elements for which a non-terrigenous source is important ( $\mathrm{Zn}, \mathrm{Ni}, \mathrm{U}$, and others) exhibit an inverse dependence on the accumulation rate of terrigenous material (Figure 21). This dependence is pronounced in the Cenozoic sediments, whereas in the Lower Cretaceous the effect of accumulation rate on concentration of the elements is insignificant. 

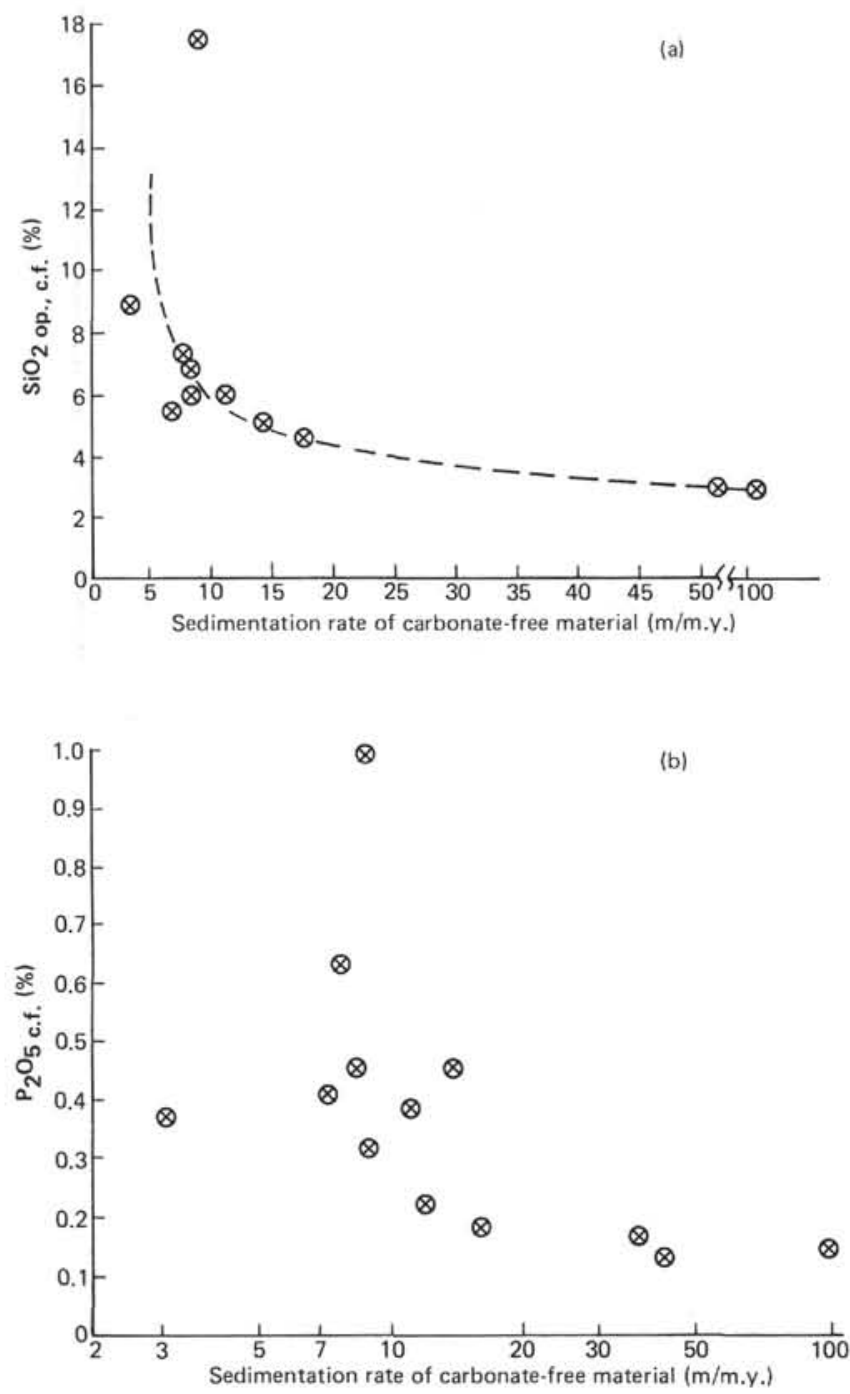

Figure 20. Variations in opaline silica content (a) and $\mathrm{P}_{2} \mathrm{O}_{5}$ content (b) as a function of sedimentation rate, calculated on the basis of carbonate-free samples, Sites 415 and 416.

In spite of the fact that the non-terrigenous contribution to the Cenozoic sediments of the Moroccan Basin is much less than that in normal pelagic muds, the differences in chemical composition and correlations of elements in the Cenozoic and the Lower Cretaceous are obvious. These differences are corroborated by the data on variation of sulfur isotopes. These data are presented in the right-hand part of Figure 22. The left half of the figure shows, for comparison, the results of $\delta^{34} \mathrm{~S}$ determinations for pyrite sulfur in modern marine sediments plotted against water depth. These data are from Kaplan et al. (1963) and Lein et al. (1976) and pertain to the shelf and continental slope of the Californian and Mexican coasts and to the Eastern Basin of the Pacific. Data of the present authors on the deposits of the Peruvian shelf, continental slope, and trench, the Peruvian and Panama Basins, Carnegie Ridge, the Hess Deep were also used, as well as the results obtained by Krouse

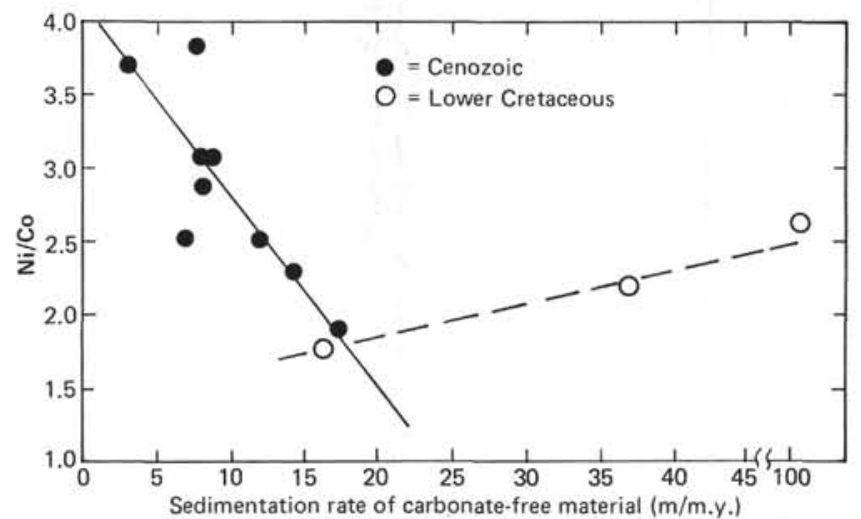

Figure 21. Variation of $\mathrm{Ni} / \mathrm{Co}$ as a function of accumulation rate of terrigenous material, Sites 415 and 416.

et al. (1977) on the Pleistocene-Pliocene deposits on the flank of the Mid-Atlantic Ridge.

Figure 22 reveals that the deep-water marine sediments have very low $\delta^{34} \mathrm{~S}$ values (sometimes as low as -54 per mill) for authigenic sulfides. Closer to the continental slope and shelf, the accumulation of the light surfur isotope in sulfides diminishes, and the $\delta^{34} \mathrm{~S}$ values increase gradually. This same trend is observed downward in the deposits of Sites 415 and 416 . The $\delta^{34} \mathrm{~S}$ values of sulfide sulfur from the youngest deposits are in the middle of the range of values for sulfur of recent deep-water sediments. The older deposits contain sulfide sulfur richer in the heavy isotope and have $\delta^{34} \mathrm{~S}$ values which correspond to those for recent deposits of the continental slope and shelf. It is only in the deepest horizons of Sites 415 and 416 that enrichment in the heavy isotope exceeds that recorded in recent shelf and slope sediments. Such enrichment is more typical of the deposits of river deltas (Thode et al., 1960) and inland fresh-water basins (Grinenko et al., 1973; Migdisov et al., 1974).

Probable variations in the conditions of sedimentation and sulfate reduction with time are shown by the relationship between $\delta^{34} \mathrm{~S}$ and organic carbon. Values for the youngest sediments of Sites 415 and 416 in Figure 18a are grouped in a field analogous to the field of values for recent deep-water sediments in Figure 18b. These sediments are characterized by low concentrations of organic carbon and a low intensity of bacterial sulfate reduction, while the amount of sulfate is rather high and the amount of the reduced sulfur low. Sulfate reduction under these conditions leads to a maximum fractionation of isotopes and the greatest enrichment of the reduced products in the light isotope, ${ }^{32} \mathrm{~S}$.

Cenozoic and Cretaceous deposits of Sites 415 and 416 which are relatively rich in organic carbon are characterized by a decrease in $\delta^{34} \mathrm{~S}$ with increase in organiccarbon content (Figure 18a); this is also typical of recent deposits of the continental shelf and slope (Figure 18b). In these deposits, the high sulfate content of the water, the considerable accumulation of organic matter in sediments, and the consequent reduced sediments on the surface result in sulfate reduction under conditions 


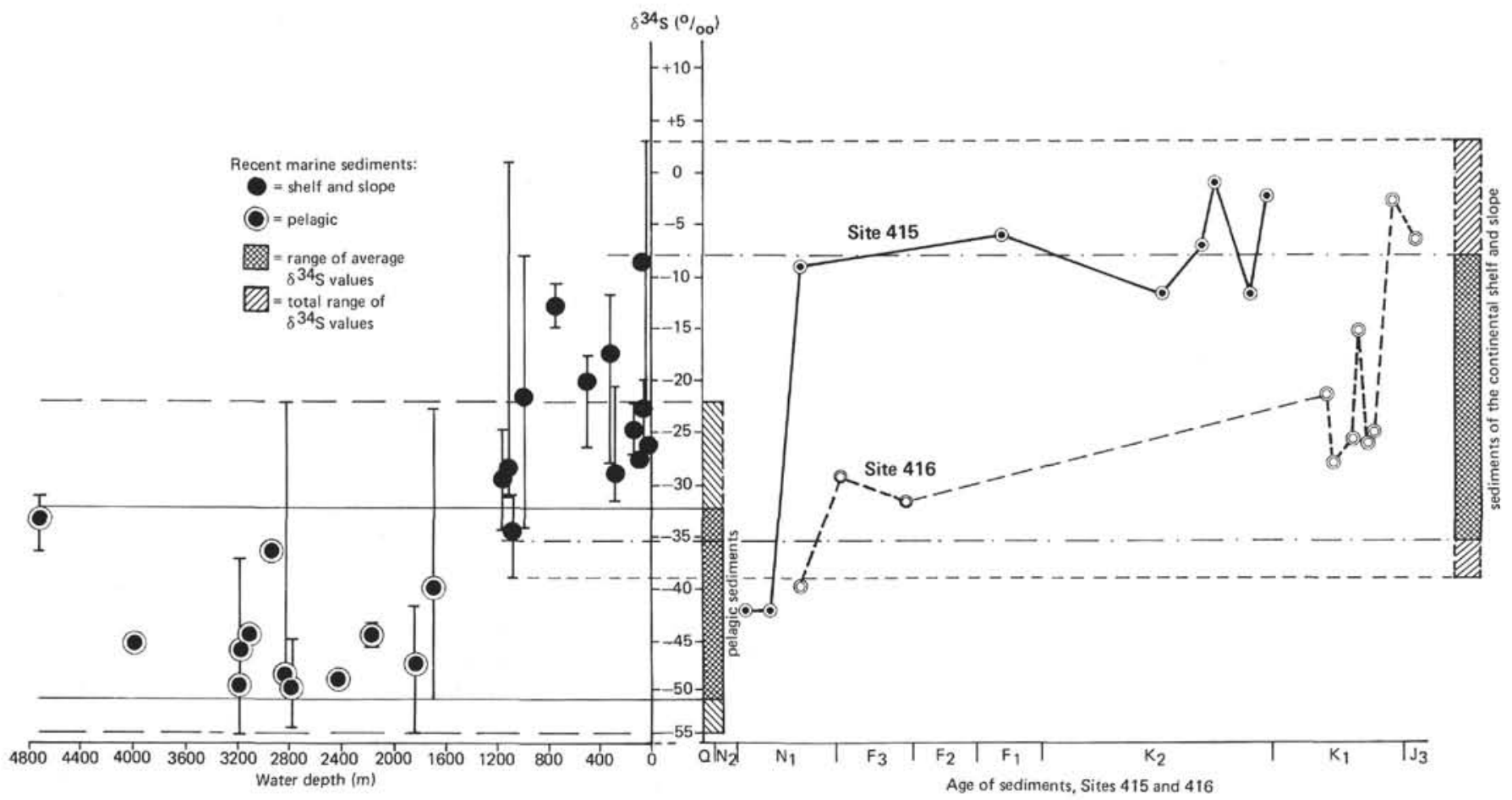

Figure 22. Comparison of the isotopic composition of sulfide sulfur in samples from Mesozoic and Cenozoic deposits of Sites 415 and 416 with those of recent marine sediments.

which approximate an open system with respect to sulfate. Under these conditions, increase in the content of organic matter favors bacterial reduction, which facilitates fractionation of sulfur isotopes.

The correlation between $\delta^{34} \mathrm{~S}$ and organic-carbon content in the Lower Cretaceous sediments (Figure 19a) is rather typical, as stated earlier, for the deposits of hyposaline basins (Figure 19b), but may be observed in the sediments of extensive river deltas as well. The originally low sulfate content in the water, the high rates of sediment burial, and the common presence of an oxidized surface layer are the factors which, together with the high organic-carbon content in the sediment and the intensive sulfate reduction, lead to a pronounced sulfate deficit in interstitial waters and to accumulation of the heavy sulfur isotope in authigenic sulfides (Grinenko and Grinenko, 1974).

Because the existence during the Early Cretaceous of a hyposaline basin at Sites 415 and 416 is apparently improbable, we can suggest that sulfides from the turbidites of the Lower Cretaceous are predominantly allogenic, much like the organic carbon and carbonates. This is in agreement with the data on transport of sulfides by rivers of modern orogenic areas (Strakhov, 1976) and with the fact that the obtained isotopic data are almost identical to those for geosynclinal rocks (Ronov et al., 1974).

Thus, sulfur-isotope analyses of samples from Sites 415 and 416 are in agreement with the conclusions on the distribution of the major and minor elements in these sections. Overall, the various data indicate that in the studied part of the Moroccan Basin pelagic sedimentation was increasingly important during the Mesozoic, at least since the Early Cretaceous, and during the entire Cenozoic.

\section{REFERENCES}

Bogolepov, K. V., and Chikov, B. M., 1976. Geology of the Ocean Bottom. Moscow (Nauka).

Boström, K., 1973. The origin and fate of ferromanganoan active ridge sediments, Acta Universitatis Stockholmiensis, Contributions in Geology, v. 27, n. 2.

Boström, K., Kraemer, T.K., and Garther, S., 1973. Provenance and accumulation rates of opaline silica, $\mathrm{Al}, \mathrm{Ti}, \mathrm{Fe}$, $\mathrm{Mo}, \mathrm{Cu}, \mathrm{Ni}$, and $\mathrm{Co}$ in pelagic sediments, Chemical Geolo$g y$, v. 11 , p. $123-148$.

Grinenko, V. A. and Grinenko, L. N., 1974. Geochemistry of Sulfur Isotopes. Moscow (Nauka).

Grinenko, V. A., Migdisov, A. A., and Barskaya, N. V., 1973. Sulfur isotopic phenomena in the sedimentary cover of the Russian Platform, Dokl. Akad. Nauk SSSR, v. 210, n. 2.

Horstman, E. L., 1957. The distribution of lithium, rubidium and calcium in sedimentary rocks, Geochim. Cosmochim. Acta, v. 12, n. 1, 2.

Kaplan, I. R., Emery, K. O., and Rittenberg, S. C., 1963. The distribution and isotopic abundance of sulfur in recent marine sediments off southern California, Geochim. Cosmochim. Acta, v. 27, p. 297-331.

Krouse, H. R., Brown, H. M., and Farquharson, R. B., 1977. Sulfur isotopic composition in DSDP Leg 37 cores. In Aumenta, F., Melson, W. G., et al., Initial Reports of the Deep Sea Drilling Project, v. 37, p. 621-623.

Lein, A. Yu., Kudryavtseva, A. I., Matrosov, A. G., and Zyakun, A. M., 1976. Isotopic composition of sulfur in the sediments of the Pacific Ocean. In The Biochemistry of Diagenesis of Sediments of the Ocean. Moscow (Nauka). 
Martin, I. H. and Knauer, G. A., 1973. The elemental composition of plankton, Geochim. Cosmochim. Acta, v. 37, n. 7, p. $1639-1954$.

Migdisov, A. A., 1960. Titanium-aluminum correlation in sedimentary rocks, Geokhimiya, n. 2.

Migdisov, A. A., Cherkovsky, S. L., and Grinenko, V. A., 1974. The dependence of the isotopic composition of the sulfur of humid sediments on their conditions of formation, Geokhimiya, n. 10.

Ronov, A. B. and Yaroshevsky, A. A., 1976. A new model of the chemical structure of the Earth's crust. Geokhimiya, n. 12.

Ronov, A. B., Grinenko, V. A., Girin, Yu. P., Savina, L. I., Kasakov, G. A., and Grinenko, L. N., 1974. The effect of tectonic conditions on the concentration and sulfur isotope composition in sedimentary rocks, Geokhimiya, n. 12.

Ronov, A. B., Girin, Yu. P., Kasakov, G. A., and Ilyukhin, M. N., 1965. Comparative geochemistry in geosynclinal and platformal sedimentary rocks, Geokhimiya, n. 8 .

Ronov, A. B., Mikhailovskaya, M. S., and Solodkova, I. I., 1963. Evolution of the chemical and mineralogical composition of arenaceous rocks. In Chemistry of the Earth's Crust, Moscow (Izdat. AN SSSR), v. 1.
Ronov, A. B., Migdisov, A. A., Voskresenskaya, N. T., Korzina, G. A., 1970. Geochemistry of lithium in the sedimentary cycle, Geokhimiya, n. 2.

Shemyakina, M. A., 1968. Determination of fluorine by attenuation in the color of the thorium-Arsenazo complex. In Questions of Applied Geochemistry, Moscow (Nedra), v. 1.

Sobornov, O. P., and Polyakov, A. I., 1975. The content of radioelements in geochemical international standards and the USSR standard rock samples, Geokhimiya, n. 2.

Strakhov, N. M., 1976. Problems of the Geochemistry of Recent Oceanic Lithogenesis. Moscow (Nauka).

Thode, H., Harrison, A., and Monster, J., 1960. Sulfur isotope fractionation in early diagenesis of recent sediments, Bull. Am. Assoc. Petrol. Geol., v. 44, n. 11.

Ustinov, V. I., and Grinenko, V. A., 1965. A Precision MassSpectrometric Method for Determining the Isotopic Composition of Sulfur. Moscow (Nauka).

Volkov, I. I., and Zhabina, N. N., 1977. New methods employed for the determination of pyritic sulfur in marine sediments. In Chemical Oceanological Investigations, Moscow (Nauka). 